\title{
Divriği Şifahanesi Ana Eyvan Tonozunun Stereotomiyası
}

\author{
Sevda ATAK ${ }^{1}$
}

Öz

Divriği Ulu Cami ve Şifahanesi, mimarlık tarihinin araştırılmasında büyük önem taşıyan taş tonoz tiplerinin programlanmasında, en önemli örneklere öncülük etmektedir. Yapıda kullanılan üst örtüler, özellikle kenar tonozlar üzerinde, birbirinden farklı olarak ciddi bir yelpaze genişliği sunmaktadır. Bu çeşitlilik, tonozların inşasında kullanılan geometrik yapı sisteminde de farklı çözümleri beraberinde getirmiştir. Dahası, Türkiye mimarlık tarihinde neredeyse, hiç bir araştırmada yer verilmeyen stereotomiya yöntemi, bu çalışmada şimdiye kadar farklı şekilde tanımlanan, 'kenar tonozlar' için uygulamalı olarak denenmiştir. Böylelikle çalışmanın hedefi olarak, Divriği Şifahanesi ana eyvanın altı kenarlı tonozunda kullanılan stereotomiya yöntemi incelenmiştir. Bu analiz üzerinden tonozun küçük bir modeli yeniden inşa edilmiştir. $\mathrm{Bu}$ işlem ve onun doğurduğu varsayımlar Madrid "Taller de Construcción Gótica" (Gotik İnşa Atölyesinde)da kabul edilen bir hipotez üzerinden gerçekleşmiştir. Madrid'de yapılan bu hipotezin doğru olması durumunda, Divriği Ulu Cami ve Şifahanesi'nin, bütün kenar tonozları için bu yöntem uygulanabilir. Bununla birlikte, aynı uygulamayı hem dönemin Selçuklu ustalarının çalışma yöntemleri anlayabilmek, hem de Selçuklu yapılarındaki benzer kenar tonozlar için de düşünmek mümkündür.

Anahtar Kelimeler: Divriği Ulu Cami ve Şifahanesi, Stereotomiya, Kenar Tonoz, Imposta, Yıldız Tonoz

\section{Stereotomy Of The Divriği Hospital's Main Iwan Vault}

\begin{abstract} Vault

\footnotetext{
Palermo Üniversitesi/Mimarlık Fakültesi/ Palermo/Sicilya/Italya

* İlgili yazar/Corresponding author: svd.atak@gmail.com,sevda.atak@unipa.it

Gönderim Tarihi / Received Date: 13.10.2019

Kabul Tarihi / Accepted Date: 22.10.2020
}

Divriği Great Mosque and Hospital leads the most important examples in programming stone vault types, which are of great importance in the research of architecture history. The top covers used in the building, especially on the groins vaults, present a serious spectrum width different from each other. This diversity has brought different solutions in the geometric structure system used in the construction of the vaults. The stereotomy method, which has never been included within the architecture history of Turkey, tried in practice for "groins vaults" that have defined in different ways so far. Thus, the study aims to examine stereotomy method used in the six-groined vault of the Divriği Hospital on the main iwan. A small model of the vault was reconstructed based on this analysis. This process and the assumptions it resulted, took place over a hypothesis accepted in the Madrid "Taller de Construcción Gótica" (Gothic Building Workshop). If this hypothesis made in Madrid is correct, this method can be applied for all groins vaults of Divriği Great Mosque and Hospital. However, it is possible to consider the same application both for understanding the working methods of the Seljuk masters of the period and for similar groins vaults in Seljuk buildings.

Keywords: Divriği Great Mosque and Hospital, Stereotomy, Groin Vault, Impost, Star 


\section{Giriş}

Divriği Ulu Cami ve Şifahanesi, XIII. yüzyıl Selçuklu Anadolusu'nun en önemli mimari eserlerinden birini temsil etmektedir ${ }^{2}$.Tamamen kesme taştan inşa edilen yapı, 1985 yılında UNESCO Dünya Kültür Mirası listesinin bir parçası olmuştur (Sakaoğlu, 2012, s. 15-16). Selçuklu çağında Anadolu'ya özgü yaratılan cami tasarım örneklerinden biri olan Divriği Ulu Cami, 1228-1229 yılları arasında Mengücekli beyi (Pancaroğlu, 2012, s. 25-67) Ahmed Şah tarafından inşa edilmiştir. Yaklaşık 32x64 metrekarelik dikdörtgen bir alanı kaplayan cami, büyük sütunlarla yirmi beş açıklığa bölünmüş, ana eksen üzerindeki orta sahın ve bunların iki yanındaki, iki yan sahından oluşan beş nefli bir bazilika planına sahiptir (Şekil 1). Caminin hemen bitişiğinde yer alan şifahane ise yine aynı yıllarda, Ahmed Şah'ın karısı olduğu tahmin edilen, Fahreddin Behram Şah'ın kızı, Turan Melek tarafından inşa edilmiştir. Şifahane, merkezi bir açıklık etrafında dört orijinal sütunla çevrili, üç eyvanın yer aldığı, giriş holü ve köşe odalarının mevcut olduğu, bunlardan kuzey-doğu köşedeki oda ise yapının banileri için ayrılmış bir türbenin de dahil edildiği bir dizi alandan oluşmaktadır.
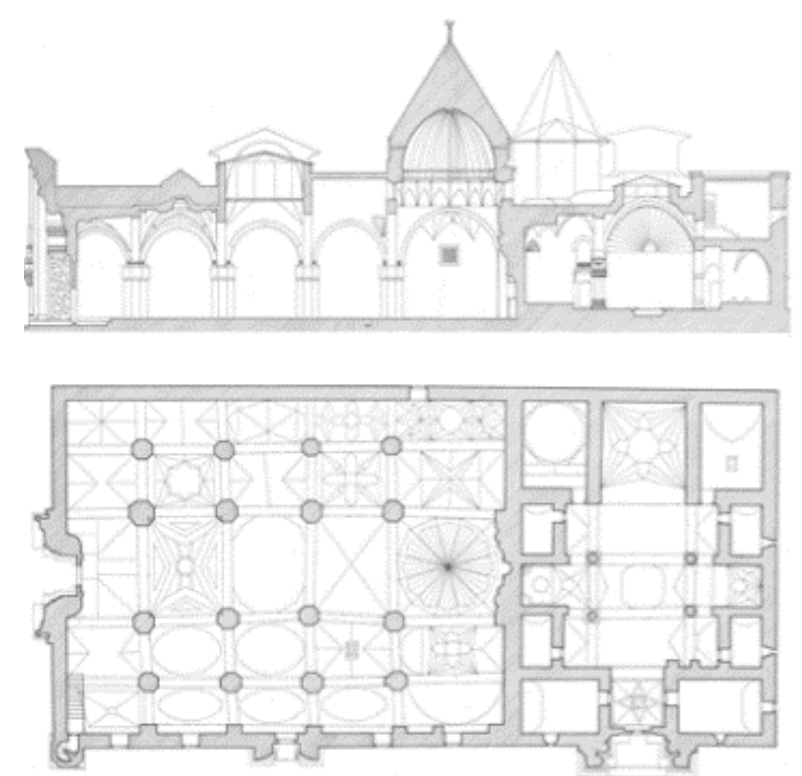

Şekil 1: Divriği Ulu Cami ve Şifahanesi'nin kesiti ve planı (Ankara Vakıflar Genel Müdürlüğü Arşivi, 1999).

Selçuklularla beraber XIII. yüzyılda, Orta Doğu Anadolu'da yaygınlaşan taş tonoz örtüsü (Atak, 2019, s. 177-208), Divriği Ulu Cami ve Şifahanesi'nde, kesme taş işçiliğinin en üst seviyesi ile karşımıza çıkmaktadır. Böylelikle onu "Divriği Mucizesi" (Kuban, 1999) yapan diğer mimari özelliklerine, açıklıklarını kaplayan tonoz dizisi de eklenmektedir. Bütün üst örtü dekorasyonunun birbirinden farklı olduğu mimari yapı, günümüze kadar sayısız değişiklikten geçmiştir (Önge, 1978, s. 33-50). Bunlardan en önemlilerinden biri XVI. yüzyılın başlarında geçirdiği tehlikeli bir deprem sonrasında, caminin batı kısmına tekabül eden tonozların yıkılmasıdır. Yıkılan bu tonozların yerine ilerleyen yıllarda küçük kubbelerden oluşan tonozlar inşa edilmiştir. Böylelikle yapının tamamında karşımıza çıkan genel simetri yoksunluğu, burada ise tonozların orijinal tasarımlarına ulaşmanın olanaksız olduğunun göstergesidir.

\footnotetext{
${ }^{2}$ Bugüne kadar Divriği Ulu Cami ve Şifahanesi hakkında farklı çalışmalar yapıımıştır. Bunlardan bazıları için; Kuban, 1968; Önge, Bayram ve Ateş, 1978; Kutluay, 1988; Kuban, 1999; Pancaroğlu, 2009; Kuban, 2010; Pancaroğlu, 2012; Peker, 2013; Atak, 2019.
} 
Divriği Ulu Cami ve Şifahanesi'nin sahip olduğu üst örtü tonoz sistemi, bazı temel tipolojilerine kadar izlenebilir. Bunlar: beşik tonoz, haç tonoz, çapraz tonoz, kaburgalı tonoz, kubbe, tromp, kenar tonoz ve kenar tonozların kombinasyonlarından oluşan birden fazla kenarlı tonozlardır (Atak, 2019, s. 74-118). Neredeyse her zaman dikdörtgen olan sahınları örten tonoz sistemi, çoğu durumda, merkez ortak düzeninde planın üç birime bölünmesiyle birlikte ortada bir merkez kare (Tükel Yavuz, 1983, s. 50) ve yanlarda ise bazen tromp, bazen çapraz tonoz, bazen de basit bir kemere indirgenerek çözüm bulmuşlardır (Şekil 2). Sonuç olarak, her bir açıklık, çeşitli tipolojilerin kombinasyonuna karşılık gelirler. Yan kısımlar duvarlarla ve merkezi kare kısım arasında bir bağlantı kurarak inşa edilmeye çalışımıştır. Böylelikle bu düzenli geometri sayesinde karmaşık örtülerin yapılması daha kolaydır.
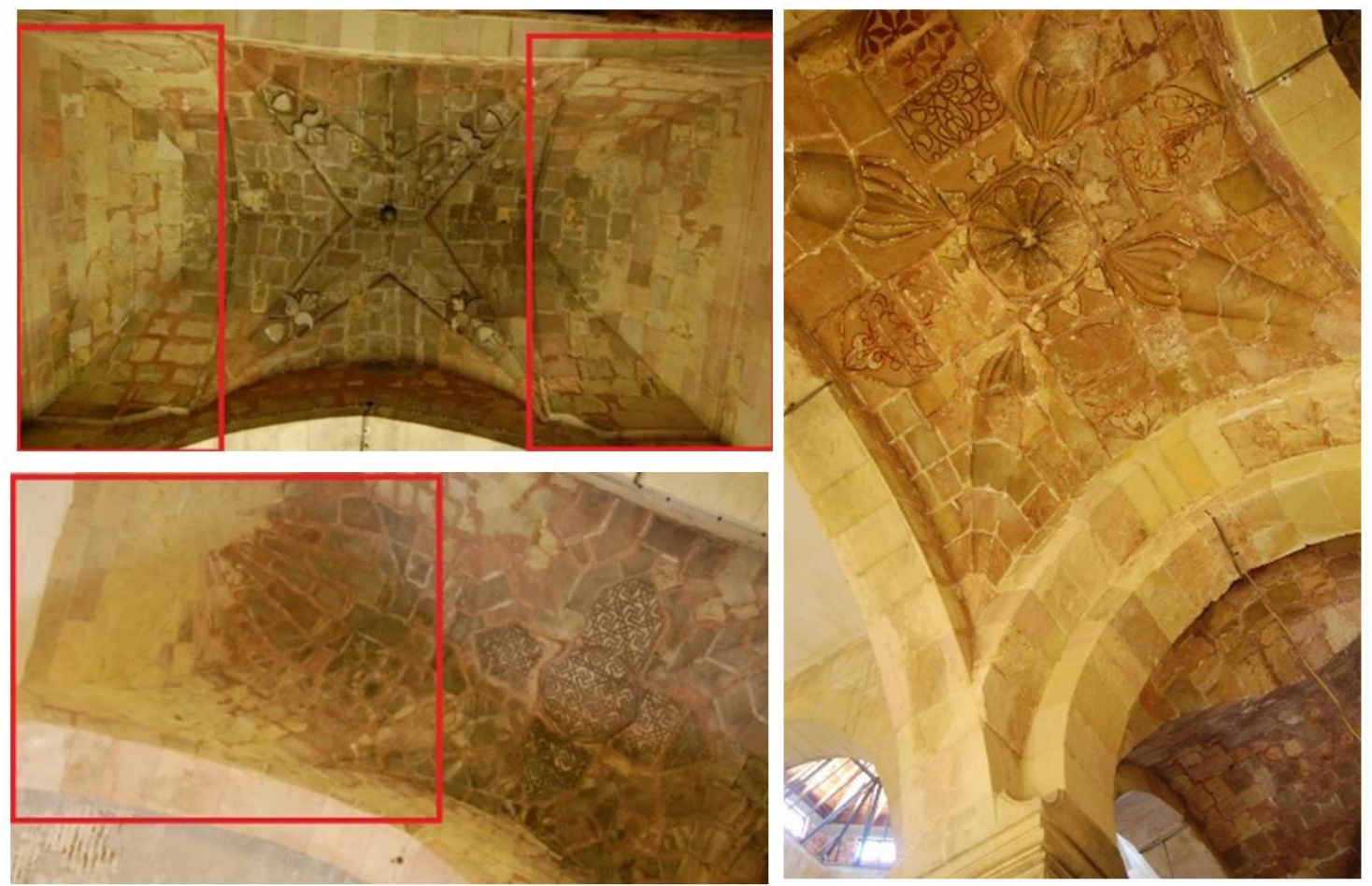

Şekil 2: Üst örtü için merkezde kare alanı elde etmek için, yanları çapraz tonoz, tromp ya da basit bir kemer ile çözümlenmiş olan Divriği Ulu Cami tonozları (Sevda Atak, 2015).

Divriği Ulu Cami ve Şifahanesi tonozlarını, dönemin mimari yapılarının üst örtülerinden ayıran en önemli özellik, kenar tonozlar üzerindeki ısrarıdır. Bu ısrar bazı durumlarda, tonozun her çeyreğinde şaşırtıcı olarak altı kenara ulaşana kadar çoğalır. Bu işlem, plandaki karmaşık ve orijinal tasarımlara karşılık gelen ve diyagonal hatların dizileriyle kesilen tonozlu yüzeylerin bölünmesini içerir. Kenarların sayısı ve buna bağlı olarak kenarların "çıkıntılı" ya da "açılı" şekilleri, tonozun merkezinde, çokgen veya haç biçimli kısmın şeklini şart koşar. Bunlara eklenen, en karmaşık olanlar ise kenar sayısının artmasına bağlı olarak, tonozun merkez yanlarına, üst örtünün düz bir şekilde son bulması ile sonuçlanan baklava formunda olanlardır.

Türk mimarlık tarihinde kenar tonozlar üzerine ilk çalışmalar Prof. Dr. Ayşıl Tükel Yavuz $^{3}$ tarafından yapılmıştır. Yavuz araştırmalarında bu tonoz türleri için planlarının genellikle yıldız biçiminde olmasından türemiş olan "yıldız tonoz" tanımını kullanmıştır

3 Prof. Dr. Ayşıl Tükel Yavuz'un yaptığı unutulmaz bir jestle, Türkiye'den Sicilya'ya, içinde tüm yayınlarının olduğu bir flash belleği tarafıma göndererek göstermiş olduğu büyük nezaketinden dolayı kendisine teşekkür ederim. Çalışmalarıma sağladığı katkı paha biçilemez. 
(Tükel Yavuz, 1978, s. 863-879). Yine aynı yazar, sonraki yıllarda, Almanca'da faltgewölbe teriminden yola çıkarak, İngilizce'de folded cross vault tanımının kullanıldığını belirtmiş ve bu tanımın doğruluğunu kabul ederek, Türkçede de "kolları katlanmış haç tonoz" olarak karşılık bulabileceğini ifade etmiştir (Tükel Yavuz, 2001, s. 179).

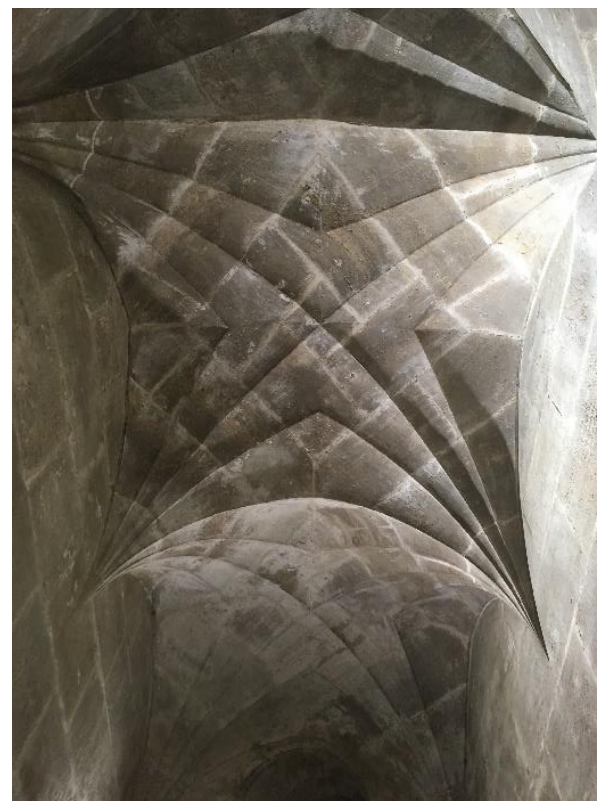

Şekil 3: Valensiya Katedrali'nin çan kulesine geçiş alanını kaplayan kenar tonozu (Sevda Atak, 2019).

$X V$. yüzyıldan itibaren İber Bölgesinde, Gotik üslubun en önemli öğelerinden olan kaburgalı tonozların yerine (Zaragozà Catalàn, 2000, s. 141-150), kenar tonozlar inşa edilmeye başlanmıştır. Bunlar kaburgasız ve kenar sayısının artmasına bağlı olarak birden fazla kenarların kombinasyonlarından oluşan tonozlardır (Şekil 3). Özellikle son yıllarda birçok derin araştırmanın konusu olan bu üst örtü sistemi, İspanyolca'da boveda de aristas (Zaragozà Catalàn, 2010, s. 177-209) yani Türkçe karşılığı "kenar tonozlar" olan bir tanım ile ifade edilmektedir. Aynı tür tonozlar İtalyanca'da ise, yine, İspanyolca tanımla aynı anlamı taşıyan volte a spigolo (Nobile, 2016, s. 45-68) şeklinde son bulmuşlardır ${ }^{4}$. Bu makalede de bu tanımlardan yola çıkarak ve bu türdeki tonozların geometrik yapılarına daha uygun olduğu düşünülen "kenar tonoz" şeklindeki ifadesi uygun görülmüştür. Çünkü Yavuz tarafından "kolları katlanmış haç tonoz veya yıldız tonoz" olarak tanımlanan bu ifade, tonozların geometrik kuruluşlarının haç tonoz ile aynı olduğunu ve yıldız tonozun statik davranışının haç tonozdan farklı olmadığını ileri sürerek tercih edilmiştir. Bundan dolayı da yazar, bu tür tonozların "bir tonoz türü değil haç tonozun yapısal bezeme ile çeşitlenmesidir" şeklinde bir ifade kullanmıştır (Tükel Yavuz, 2001, s. 177). Oysa ki bu tür tonozlar, her zaman bir haç tonozun uzantısına sahip olmamakla beraber, temellerinde bazen çapraz tonoz planı da yer alabilir. Bu durum, tonozların diyagonalleri gözlemlenerek rahatlıkla ayırt edilebilir. Üst örtüde, eğer tonozun diyagonalleri yüzeyde "çıkıntılı bir kenar" oluşturuyorsa haç tonoz (Şekil 4), eğer "girinti bir kenar" oluşturuyorsa temelde bir çapraz tonoz planı (Şekil 5) uygulanmıştır.

\footnotetext{
${ }^{4}$ Yavuz'un ilk ifadesinde olduğu gibi, tonozun geometrik yapısından daha çok, oluşturduğu şekilden kaynaklı olarak "yıldız tonoz" tanımı, İtalyan mimarlık tarihinde de bazı araştırmalarda volte a stella (Boata, 2005, 67) yani Türkçe'deki tam karşıı̆ı ile "yıldız tonoz" şeklindeki ifadesi bu ifade ile de karşılaşmak mümkündür. Ancak bu ifade daha karmaşık olan kenar tonozlardan daha çok, daha genel olan "iki kenarlı tonozlar" için tercih edilmiştir.
} 

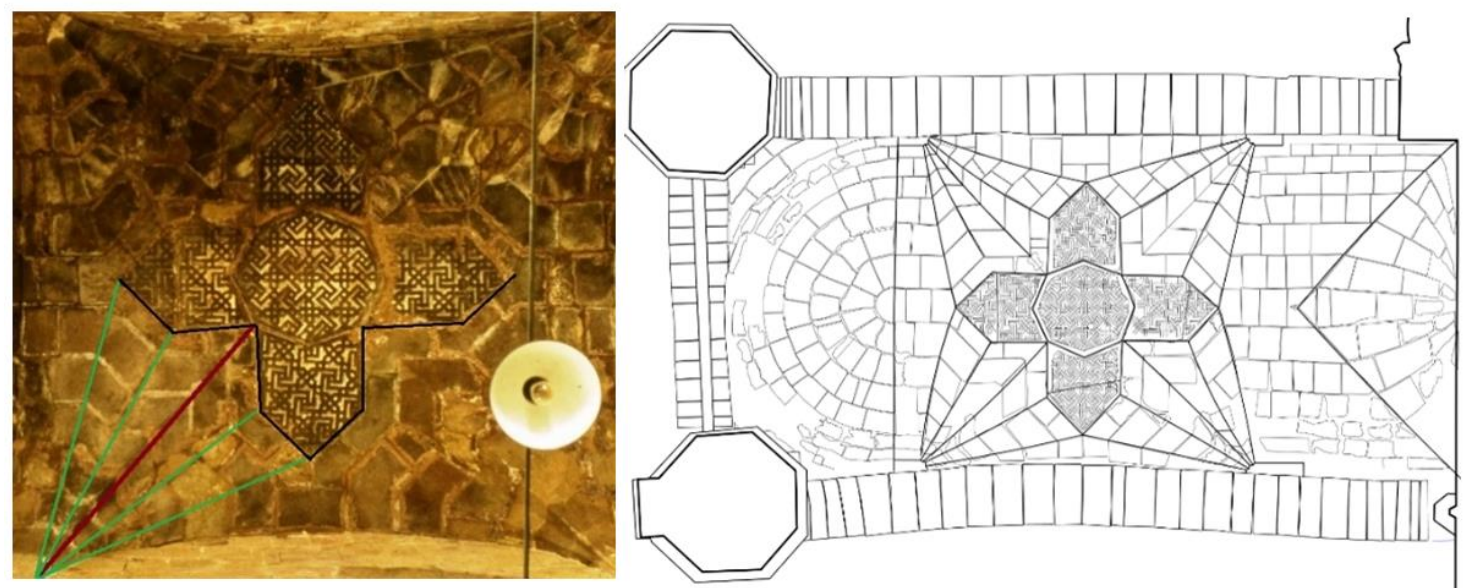

Şekil 4: Temelde bir haç tonoz planı uygulanan Divriği Ulu Cami 5 kenarlı tonozu (Sevda Atak) ve planı (Ankara Vakıflar Genel Müdürlüğü Arşivi,1999).
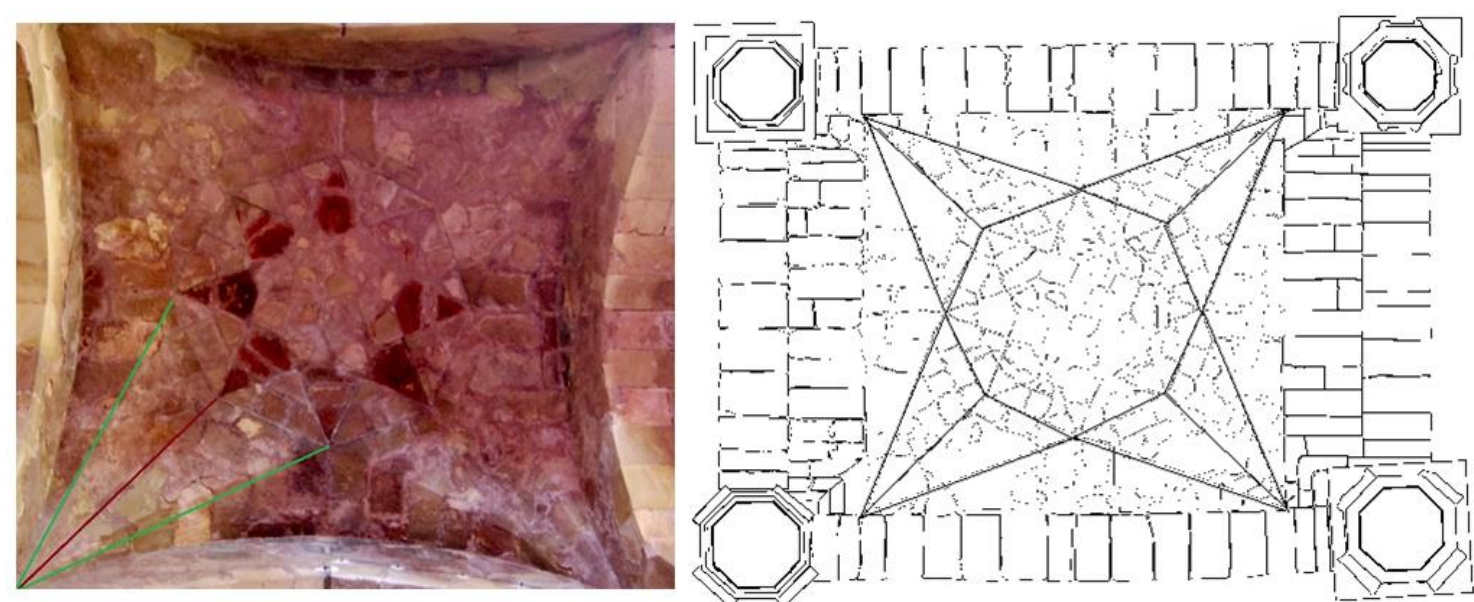

Şekil 5: Temelde bir çapraz tonoz planı kullanılan Divriği Ulu Cami 3 kenarlı tonozu (Sevda Atak) ve planı (Ankara Vakıflar Genel Müdürlüğü Arşivi, 1999).

$\mathrm{Bu}$ durumda diyagonal çizgilerinin girinti ya da çıkıntılı şekli tonozun temel planını belirlemektedir. Dolayısıyla çıkıntılı ve girintili kenarlar arasındaki bu temel fark, kesme taşların kesim kriterinde ortaya çıkmaktadır. $\mathrm{Bu}$ da şantiyede uygulanan işlem bakımından çıkıntılı kenarlarda haç tonozun yerine gösterilen yöntemler kullanılırken, girintili kenarlarda ise çapraz tonoz kullanılır. Böylelikle haç tonoz olumsuz düşünülebilir. Kesme taş sıralarının ön grafik model çizimlerinin, incelenen durumda da olduğu gibi, özellikle çıkıntı ve girintileri şekillerini tek bir taş üzerinde kesmenin zorunlu olduğu durumlarda, bu çoğaltma yöntemi, şantiyeye büyük kolaylıklar sağlayarak gerçekleşir.

Anadolu Selçuklu mimarisi, köşegen çizgiler, dolayısıyla kenarlarda ve yüzeyde oluşturdukları girintili açıların sayısına göre sınıflandırılabilen şaşırtıcı bir çok çeşit kenar tonoz örnekleri sunar (Tükel Yavuz, 1993, s. 165-192). Bunlar iki ${ }^{5}$, üç ${ }^{6}$, beş $^{7}$, altı,

\footnotetext{
${ }^{5}$ Bunlardan iki kenarlı tonozlardan bazıları: 1278-1279 tarihli Çay'da yer alan Yusuf bin Yakup türbesinde, diğer bir örnek, 1371 tarihli Mardin Latifiye Cami'nin çeşme eyvan üst örtüsünde, daha geç tarihli başka bir örnek ise, Bursa Yeşil Cami'nin (1419-1420) yabancı konukların kabulü için tasarlanmış ve yapının köşelerine yerleştirilmiş iki oda, iki kenarlı tonozlarla örtülüdür. Yine Bursa Yeşil Külliyesi'inde yer alan, Yeşil Medrese'de de iki kenarlı tonoz örnekleri mevcuttur. ${ }^{6}$ Üç kenarlı örneklerden bazıları ise; Alara Han'ın (1231) çeşme eyvan tonozu, Tuzhisar Sultan Han'ın (1230-1234) giriş eyvan tonozu, Karatay Han'ın (1241) giriş eyvanının hemen güney yan odanın üst örtüsü, Erzurum Çifte Minareli Medresesi'nin (XIII. yy) batı eyvan tonozu, Sivas Gök Medresesi'nin giriş eyvan tonozu ve son olarak da beylikler dönemi eseri olan Selçuk İsa Bey Cami'nde (1374) yer almaktadır.
} 
yedi ve dokuz kenarlı tonozlardır ${ }^{8}$. Bunlardan Türkiye Selçuklu mimarisinde en yaygın olarak kullanılan üç kenarlı tonoz iken (Tükel Yavuz, 1978, s. 34; Tükel Yavuz, 1993, s. 550), kenar sayısı arttıkça azalma göstermekte ve altı kenarlı olan tek örnek (Tükel Yavuz, 1993, s. 555) Divriği Şifahanesi'nin ana eyvanını örtmektedir (Atak, 2019,s. 188-209). Bu tonoz, belki de kompleks stereotomiyasın ${ }^{9}{ }^{9}$ zirvesini temsil etmektedir ${ }^{10}$. Düz bir merkezden oluşan ve her çeyreğinde altı kenar bulunduran bu tonozun merkezinde, kenarları eşit olmayan bir sekizgen mevcuttur. Sekizgenin dört kenarı tonozun kenarlarına paralel olarak yerleştirilmiş ve bunların uçları geometrik motiflerle süslenmiş düzgün olmayan beşgen biten dört kollar merkezde haç biçimini oluşturmuştur. Sekizgenin ortasına bir çift spiral işlenmiş ve kırmızı çizgilerle dekore edilmiştir.

Tonoz, tüm köşelerinden çıkan kenar hatlarının çıkıntı ve girintilerinin değişimine göre inşa edilmiştir; çift sayıdan oluşan kenar numarası, diyagonal boyunca konumlandırılmış, üzeri bir yarım istiridye şeklinde biten ve konik olarak oyulan bir yüzeyden oluşmaktadır (Şekil 6). Bunun benzeri, yine, Divriği Ulu Cami kubbesinin kuzey-doğu çaprazında yer alan bir haç tonozda da tekrar eder ${ }^{11}$.

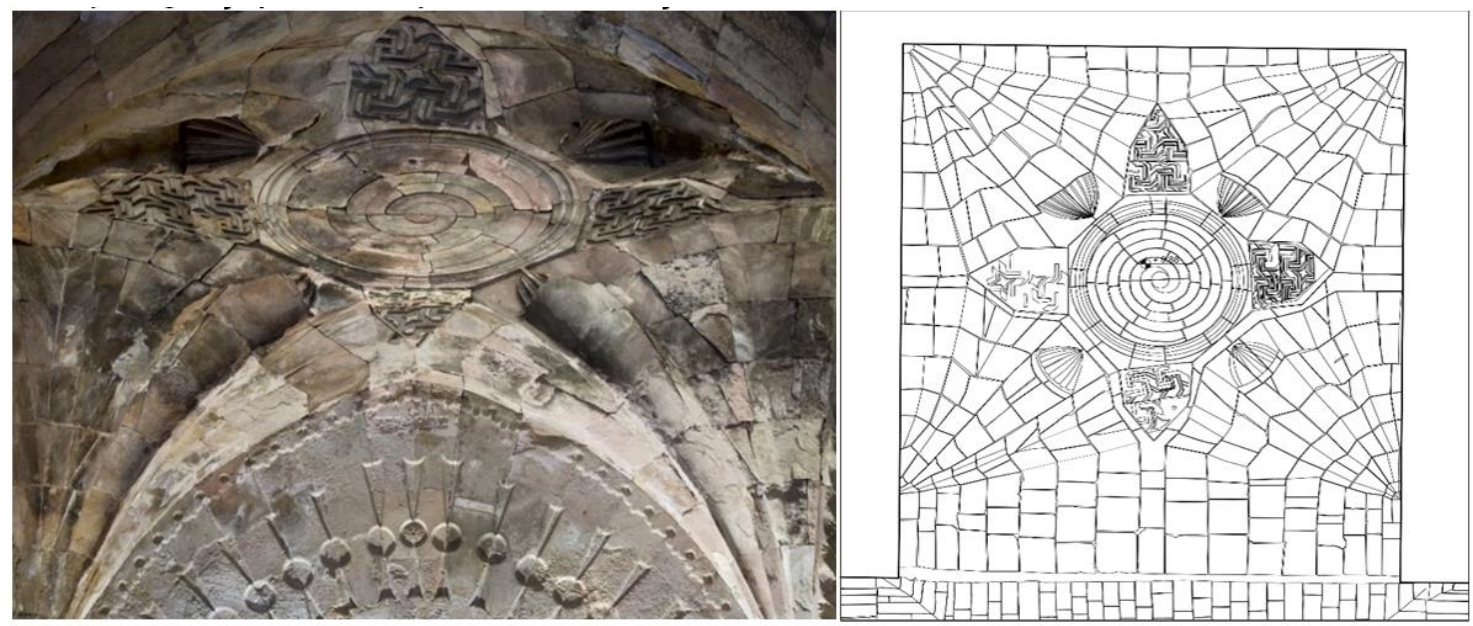

Şekil 6: Divriği Şifahanesi'nin altı kenarı tonozu (Sevda Atak) ve planı (Ankara Vakıflar Genel Müdürlüğü Arşivi,1999).

Spiral bir tasarımla meşgul olan altı kenarlı tonozun merkez kısmının sadece bazı bölümleri kesme taşların gerçek birleşme yerlerine denk gelmektedir ${ }^{12}$. Böylece tonozun merkez inşasında kullanılacak olan kesme taş sayısı, bu küçük hile ile oldukça

\footnotetext{
${ }^{7}$ Beş kenarı tonoz örnekler ise; Iğdır Kervansarayı'nda (XIII. yy) giriş alanının örtüsü, Mardin Zinciriye Medresesi (1385) üst örtüsü, Mardin Melik Mahmut Cami'nin (XIV. yy) giriş eyvan örtüsü ve son olarak da Mardin Kasimiye Medresesi'nde (XIV-XV. yy) revağının merkez tonozunun iki yanında yer alan iki tonozlar örnek verilebilir.

${ }^{8}$ Mardin Kasimiye Medresesi (XIV-XV. yy) revağının merkez tonozu ve iki çeşme eyvan tonoz örtüsü dokuz kenardan oluşmaktadır.

${ }_{9}$ Sterotomiya, Yunanca stereos "katı" ve tome "kesme" kelimelerinden türemiş, eski tanımı ile bir kesme taş sanatıdır. $\mathrm{Bu}$ sanat inşaatta uygulanabilmesi için taş, tuğla ahşap veya metalleri kesmek için gerekli bir teknik olarak tanımlanabilir. Geometriye dayanan bu teknik, duvarların, kemerlerin, tonozların veya taş işlerindeki herhangi bir mimari figürün tanımlanmasına onay vererek, kesme taşların her birinin şeklini önceden belirlenmesine ve dolayısıyla inşaat sürecini temsil etmesine izin verir. Yani sürecin özeti, kaba haldeki yapı elemanlarının, karmaşık geometride tasarlanan biçimlerini oluşturacak şekilde kesilmesi ve onların geleneksel yöntemlerle oluşturulmuş taslaklar eşliğinde, yapı elemanlarını oluşturacak şekilde birleştirilmesidir. Bu yüzden stereotomiya basit taş kesme işlemleri ile ilgilenmez, ancak kesme taşlarda yapısal elemanları tasarlamak için kodlanmış geometrik prosedürleri ön görmektedir. Daha detaylı bilgi için:(Palacios Gonzalo, 2003; Rabasa Diaz, 2009, s. 50-69; Zaragozà Catalàn, 2010, s. 190-191, Trevisan, 2011, s. 913).

${ }^{10}$ Bununla beraber Divriği Ulu Cami ve Şifahanesi'nde de iki, üç, beş ve kenarların kombinasyonlarından oluşan kenar tonozlar mevcuttur.

${ }_{11}^{11}$ Bu tonoz ile ilgili daha detaylı bilgi için; (Atak, 2019,s. 82-83).

${ }^{12}$ Ana eyvan örtüsünün spiral merkezli düz tonozunun inşası ve geometrik analizi için; (Atak, 2020, s. 69-96).
} 
azaltılmıştır. Buna rağmen taş tonoz inşaatı için uygulanacak olan yöntem, ciddi bir şekilde kodlanmış geometrik prosedür gerektirmektedir. Bu da yapının birçok alanında olduğu gibi, incelenen durumda da, bu ana eyvan tonozu için, özel bir alanın örtüsü olarak tesadüfen değil, tüm yapının en fazla sayıda kenarı olan tonozunun istisnai karakterini doğrular niteliktedir (Şekil 7).

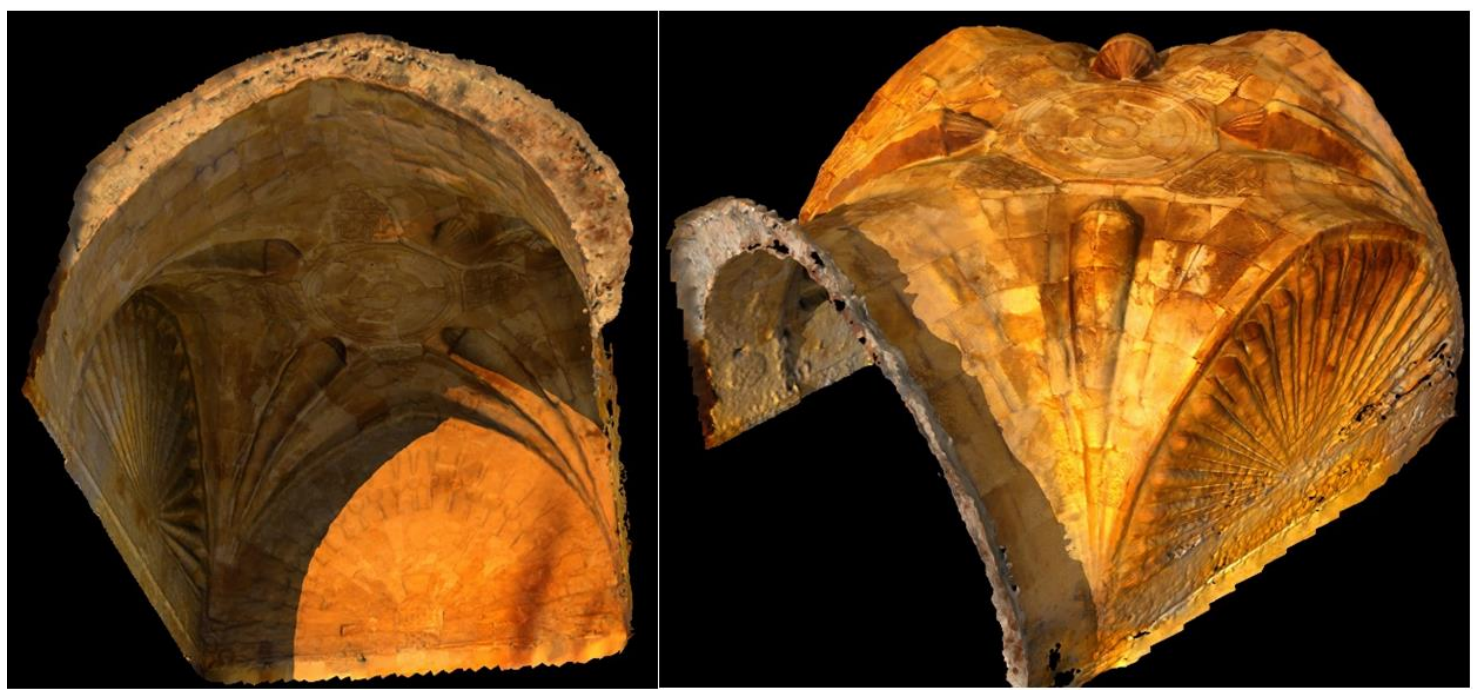

Şekil 7: Divriği Şifahanesi ana eyvan altı kenarlı tonozunun aşağıdan ve yukarıdan 3D görünümü (Fabrizio Agnello ve Laura Barrale)

\section{Divriği Altı Kenarlı Ana Eyvan Tonozunun İnşası ve Geometrik Analizi İçin: Gotik İnşaat Atölyesi Deneyimi}

2017 yılında, Prof. Dr. José Carlos Palacios Gonzalo öncülüğünde, Madrid Politeknik Üniversitesi Mimarlık Fakültesi'nde düzenlenen master programı kapsamında gerçekleşen "Taller de Construcción Gótica" (Gotik İnşa Atölyesinde ${ }^{13}$ )da Divriği Şifahanesi ana eyvan altı kenarlı tonozunun küçük bir modeli yeniden inşa edilmiştir. Araştırmanın doğru sonuç verebilmesi için, öncelikle tonozun gerçek plan ölçülerine intiyaç duyulmaktadır. Ancak Divriği Ulu Cami ve Şifahanesi için 2015 yılında başlayan restorasyon çalışmasının halen devamı sebebiyle, binaya erişimin imkansızlığından dolayı, altı kenarlı ve düz merkezli tonozun stereotomiyası için, 1999 yılında, O.D.T.Ü Mimarlık Fakültesi tarafından hazırlanan Divriği Ulu Cami ve Şifahanesi rölöve çalışmalarına, Ankara Vakıflar Genel Müdürlüğü Arşivi'nden ulaşılmıştır. Lakin arşivden alınan, bu mevcut tek rölöve ile, yapının restorasyon çalışmasına başlamadan birkaç ay önce tarafımdan çekilen fotoğraflar karşılaştırıldığında, incelenen tonozun rölövesinin doğru olmadığı fark edilmiştir. Tonozun düz merkezini kaplayan spirali oluşturan kesme taşlar, gerçek birleşme yataklarına göre değil, üzerlerine işlenmiş olan yalancı spiral süslemeler varsayılarak hazırlanmıştır (Şekil 8).

\footnotetext{
${ }^{13}$ Birkaç yıldır, Madrid Politeknik Üniversitesi, geleneksel ahşap, tuğla, taş ve alçı yapım teknikleri üzerine master programı düzenliyor. Eğitim kursunun önemli anları, genellikle daha önce 3D grafik yazılımı ile incelenen ve yeniden oluşturulan, çoğunlukla İber tonozlarının modellerinin (çoğu zaman 1: 2 ölçekte) gerçekleştirildiği, gotik bir mimari şantiyenin simülasyonudur. Multimedya teknolojilerinin desteği hariç, tüm yapım süreci, Gotik şantiyede kullanılanlarla kıyaslanabilecek yöntem ve araçlardan yararlanır, böylece stereotomiya alanında yapılan tarih araştırmalarını test etmek ve belirli durumlara uygulamak için kullanılır. Divriği hastanesinin sarmal merkezli altı kenarlı tonozu, Mart ve Temmuz 2017 tarihleri arasında gerçekleştirilen atölyenin konusuydu.
} 

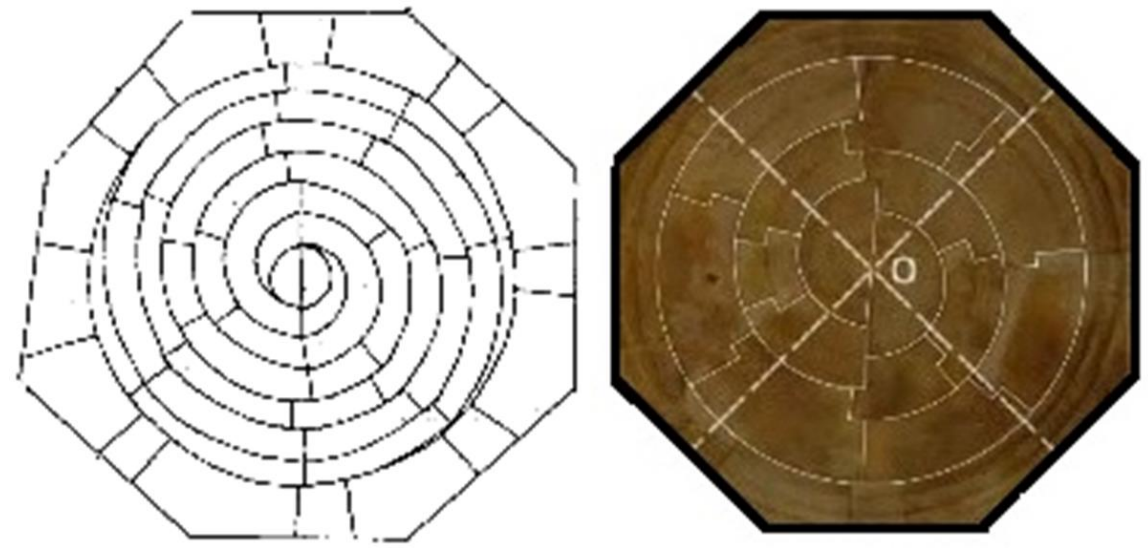

Şekil 8: Ankara Vakıflar Genel Müdürlüğü Arşivi'nden alınan ve gerçek kesme taş eklem yerlerine göre yeniden tasarlanan Divriği Şifahanesi ana eyvan tonozunun spiral merkezinin planı (Sevda Atak).

Tonoz sekizgenin ortasında yer alan spiral araç, Ankara Vakıflar Genel Müdürlüğü Arşivi'nden alınan tasarımın aksine gerçek eklem yatakları, radyal eklemler üzerinde sistematik olarak tekrarlanarak ve hafif bir kaydırmaya bağlı üç eş merkezli halkadan oluşmaktadır. Bununla birlikte karşılıklı kenetlenmeyi gerçekleştiren testere dişi profiline de sahiptirler. Sonuç olarak, on beş kesme taştan oluşan spiralin her bir kesme taşı, kilit taşını oluşturan iki yarım daire şeklinde olan iki parça dışındaki, her bir kesme taş diğerinden farklıdır (Şekil 9).
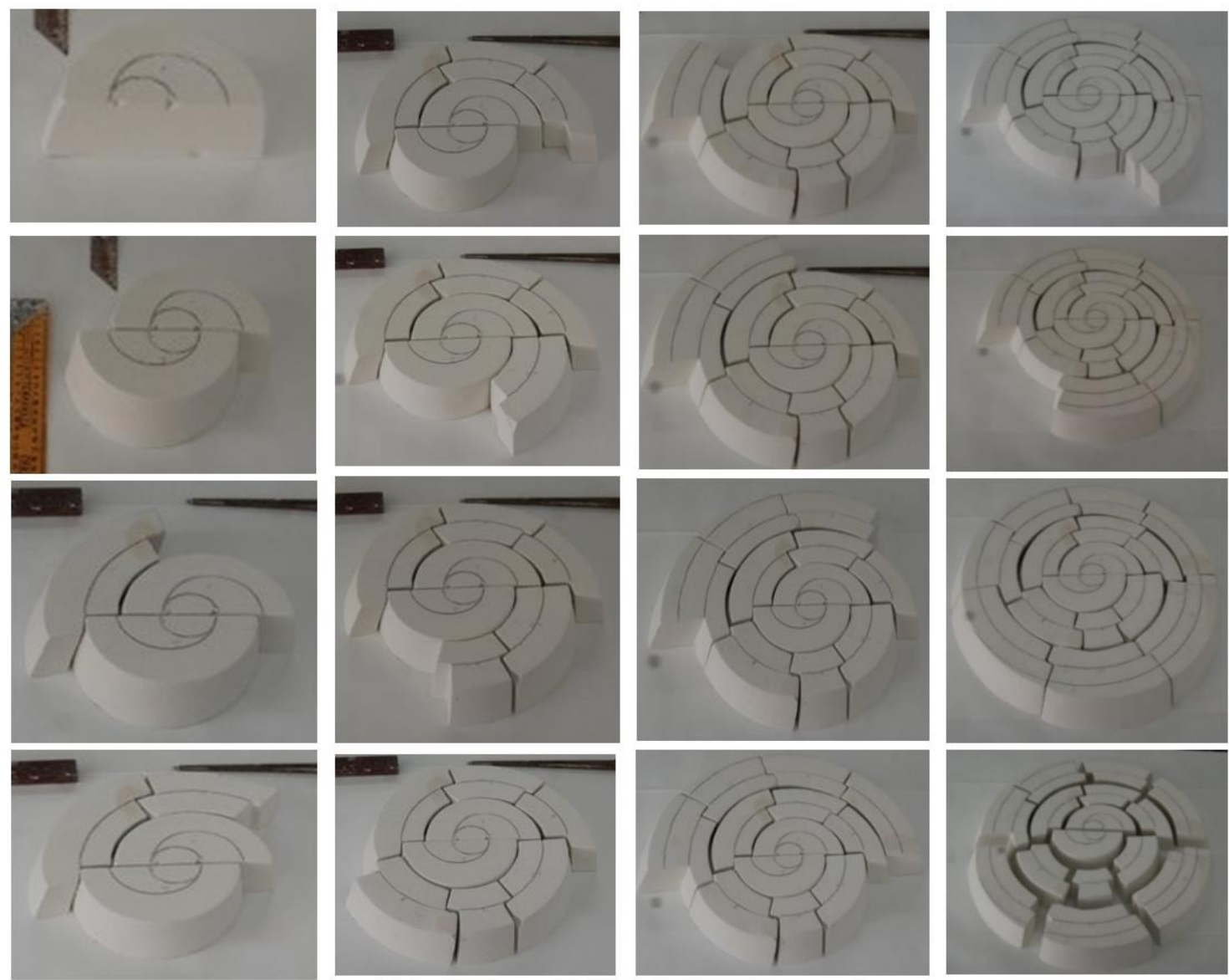

Şekil 9: On beş kesme taştan oluşan spiral merkezin gerçek eklem yataklarına göre yeniden inşası (Sevda Atak, 2017). 
$\mathrm{Bu}$ farklılık, spirali oluşturan her bir kesme taş için seri bir şekildeki üretimi engelleyerek, bunların her biri için farklı bir şablon gerektirmektedir. Dahası, özenle hazırlanmış bir geometri bilgisini de zorunlu kılmaktadır. Bu da Divriği Ulu Cami ve Şifahanesi'nin neredeyse tümünde karşımıza çıkan ünik özelliğini vurgular niteliktedir. Neticede çalışmanın hedefi olarak, Divriği Şifahanesi ana eyvan tonozunun yeniden inşası deneyiminde, tonozu oluşan kesme taşların geometrisi incelenmiş ve olası yapım prosedür varsayımları yapılmıştır. Deneyde karşılaşılan zorlukları ve ortaya çıkan geometrik ve yapıcı etkileri gösteren bir prosedür ile açıklanmaktadır.

\section{1. İmposta ya da Üzengi taşı?}

Divriği Şifahanesi ana eyvan tonozunun yeniden inşası için ilk adım, alt kısmın yapıcı sisteminin kenarlarda tanımlanmasından oluşur. Demek ki, hangi noktadan sonra yatay yerleştirme yataklarının eğilimli olduklarının belirlenmesindedir. Avrupa'daki Gotik yapı üzerine yapılan araştırmaların gösterdiği gibi, bu durum kolaylıkla tanınabilir. Öncelikle Ankara Vakıflar Genel Müdürlüğü Arşivi'nden alınan rölöve çalışmasının alan ölçülerinden ve mevcut fotoğraflardan yararlanarak, başlangıç tasarım şemasında belli uyarlamalar yapılır. Bununla birlikte şantiye modifikasyonları ile oluşturulan bir yapının varlığında gerçekleşen yapı sistemi, hipotezlerle ilerleyerek yeniden inşa edilir. Bazen de atölyenin alıştırması için uygun bir modele, örnek olay geri getirilir. Ortaya atılan hipotez sonrasında modeli yatay sıralarda yapma olasılığı dışında, daha yüksek yerlerdeki yani tonozun merkezine daha yakın olan kesme taş sıralarının, çok keskin açılara sahip olabileceği bir durum, sekiz sıranın en az ikisinin eğimli yataklara döşenmesi sonucuna varılması gerekliliğini göstermiştir. Bu durumda, tonozun başlangıç noktasından başlayarak, ilk altı sıranın yatay yerleştirme yataklarına sahip olduğu ileri sürülebilir.
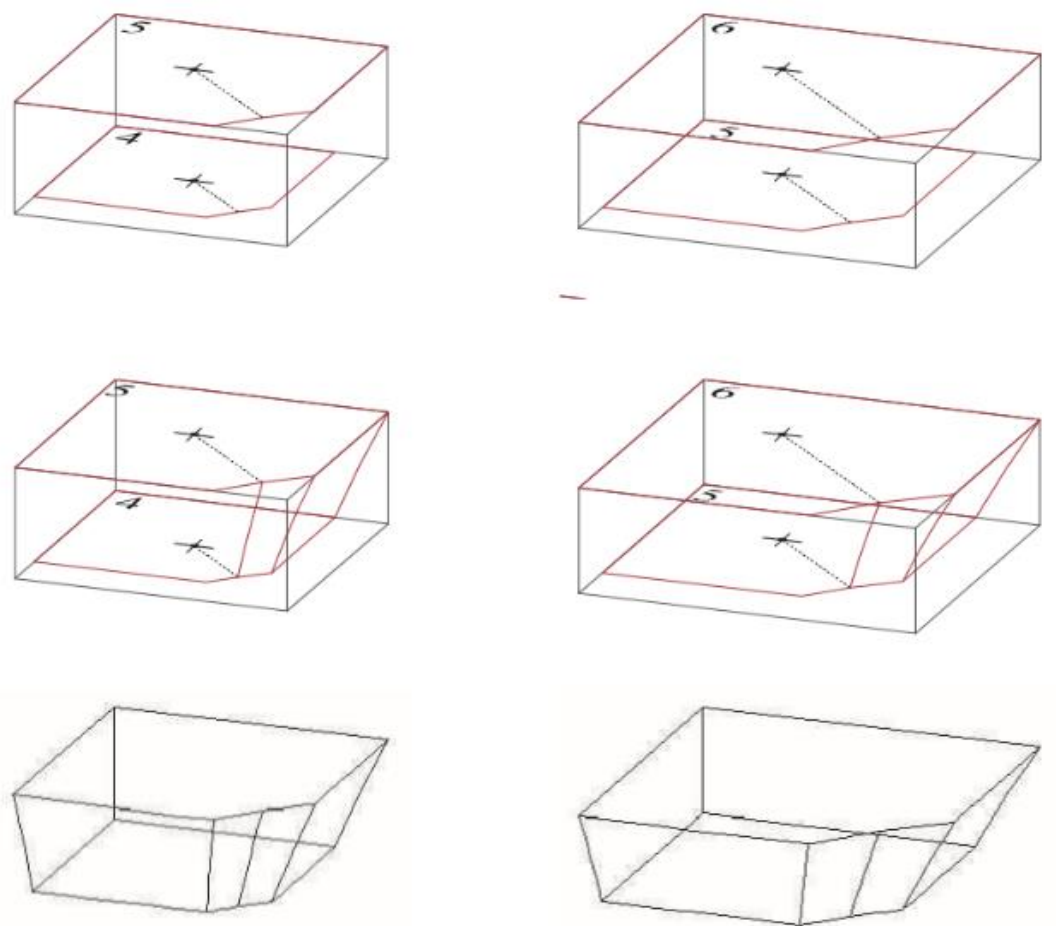

Şekil 10: Bir kenar tonozun impostasını oluşturan örnek bir kesme taşın, alt ve üst yüzeyinin yatay olarak kesimi (Sevda Atak). 


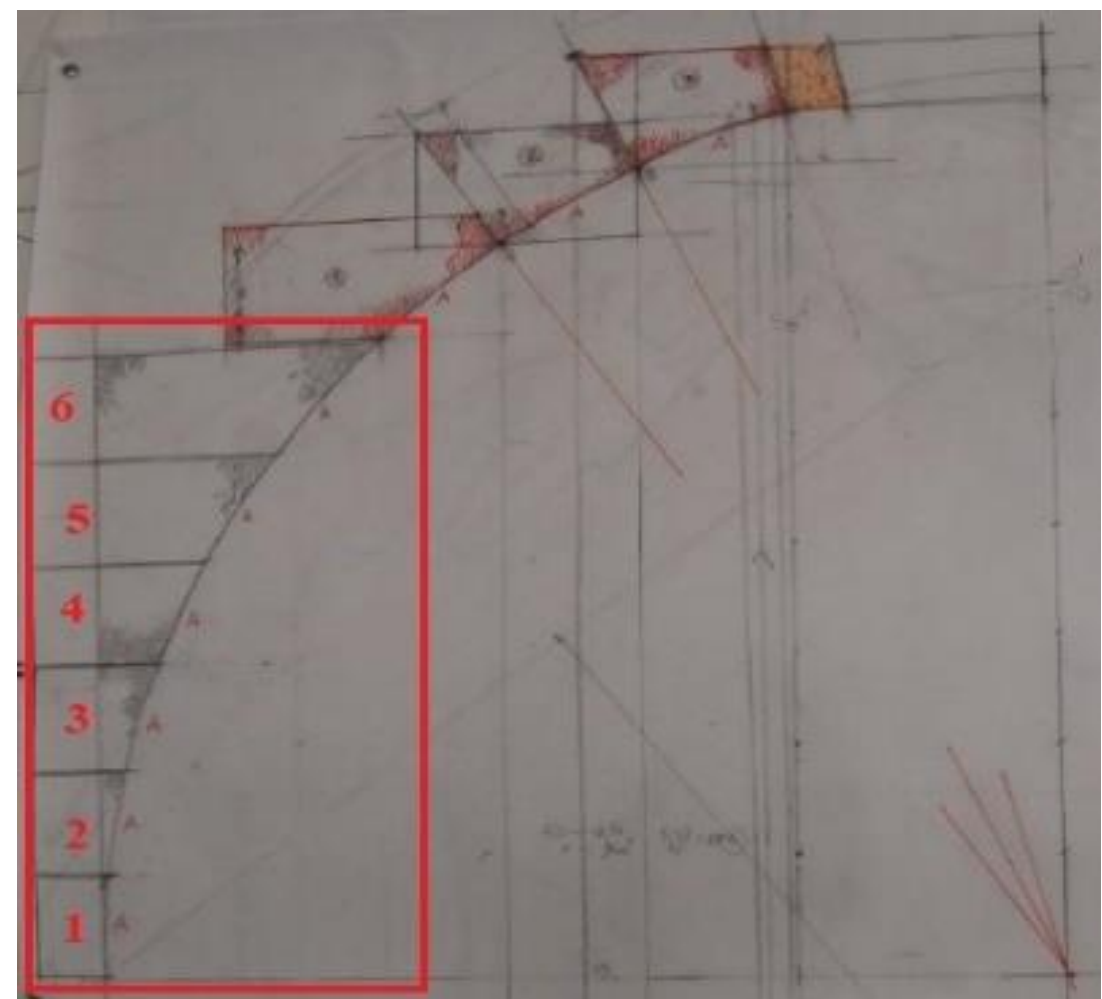

Şekil 11: Divriği Şifahanesi altı kenarlı tonoz için impostanın tanımlanması (Sevda Atak, 2017).

Bununla beraber bu yatay sıralardan oluşan kesme taşların, Türkçe mimarlık terminolojisinde tam anlamıyla karşılığı bulunamamıştır. Aslında bu kısım, tonozun köşelerinde, üzengi taşı üzerinde, kemerlerin birleştiği ve bir araya gelerek kesiştiği yerdir. Bu üç boyutlu hacim, çevre duvarlarına birleştirilmiş yatay sıralardan oluşmaktadır. Bilindiği üzere üzengi taşı, bir kemerin ayağa oturduğu noktadaki ilk taştır. Üzengi taşının ayak üzerine gelen yüzeyleri yatay, üst yüzeyleri ise kemer eğrisine uygun olacak şekilde eğik tasarlanır. Burada ise, bu terim ile tanımlanmak istenen, bir kesme taşın hem alt, hem üst yüzeylerinin yatay olarak kesilmesidir (Şekil 10). Yani birden fazla üzengi taşının (bu durumda aslında her kesme taşın) üst ve alt yüzeylerinin yatay bir şekilde üst üste gelmesi ile tonozun inşası sırasında oluşan yatay kısımlardır. İşte bu yatay kesme taş sıralarından oluşan tonoz bölümünün Türkçe terminolojisinde tam bir tanımı mevcut olmamakla birlikte, İspanyol mimarisinde jarja (Palacios Gonzalo, 2003, s. 290), Fransızca'da tas de charge ${ }^{14}$ Italyanca'da ise imposta olarak ifade edilmektedir. İncelenen bu durumda tonozun başlangıç noktasından itibaren ilk altı sıranın oluşturduğu yatay sıralar (Şekil 11) için, tıpkı İtalyan mimarisinde olduğu gibi "imposta” şeklindeki ifadesinin kullanımı uygun görülmüştür.

\subsection{Divriği Şifahanesi Ana Eyvan Altı Kenarlı Tonozunun Kesim Hatlarının Belirlenmesi İçin Geometrik Analiz}

Hipotezdeki ilerlemeye göre, sıraların izlenmesi için başlangıç noktası, temel geometrik şemanın plan çizimidir. Tonozun alan ölçüleri Vakıflar Genel Müdürlüğü Arşivi'nden

\footnotetext{
14 Kelimenin tam anlamıyla "kütle" veya "yığın" anlamına gelen Fransızca terimin çevirisi zor; haç tonozların stereotomiya ve yapım detaylarına atıfta bulunularak, İtalyan teknik sözlüğünde, Fransız veya İspanyol terminolojisi gibi belirli ve açık bir terminoloji yoktur. Aynı durum Türk terminolojisi için de söz konusudur. Tas-de-charge'in daha eksiksiz bir tanımı için bakınız: (R. Díaz, 2000, s. 96-104; Navarro Fajardo, 2006, s. 167-175; Pérez de los Ríos ve Zaragozá Catalán, 2013, s. 833).
} 
alınan rölövenin ölçüleri ile aynı tutulmuştur. Ancak tonozun geçirmiş olduğu deprem ya da çeşitli tahribatlar göz önünde tutularak ve yapılan deneyin daha iyi sonuç verebilmesi için tonozun merkezinde yer alan düzgün olmayan sekizgenin ve bunun dört kenarında yer alan düzgün olmayan beşgenlerin, sanki düzgün sekizgen ve beşgen olduğu varsayılarak tonoz planı yeniden tasarlanmıştır. Her çeyrek, altı kenarı baz alan, haç kollu ve merkezinde bir sekizgen oluşturan dört katlamadan meydana gelir. Bu yüzden tonozun bir çeyreğinin yarısında yapılan işlem bütün çeyreklerine karşılık geldiğinden, işlemi tek bir çeyreğin yarısında gerçekleştirmek yeterlidir.

Divriği Şifahanesi ana eyvan altı kenarlı tonozunun diyagonalleri üzerinde konik olarak oyulmuş kısım, diyagonal çizgilerinin kaybolmasına neden olduğundan, köşegenlerin kesişimini boşluktaki kenarları çizilen çember yaylarının orjini olarak kabul edilir. Böylelikle bir kesit planı üzerinden bunların profilini düşürerek çizmek mümkündür. Öyleyse diyagonallerin kesiştiği (“O”) nokta, yatay eksen üzerinden ilk düşürülen ve daha sonra üzengi yüksekliğini belirleyecek olan noktadır (Şekil 12).

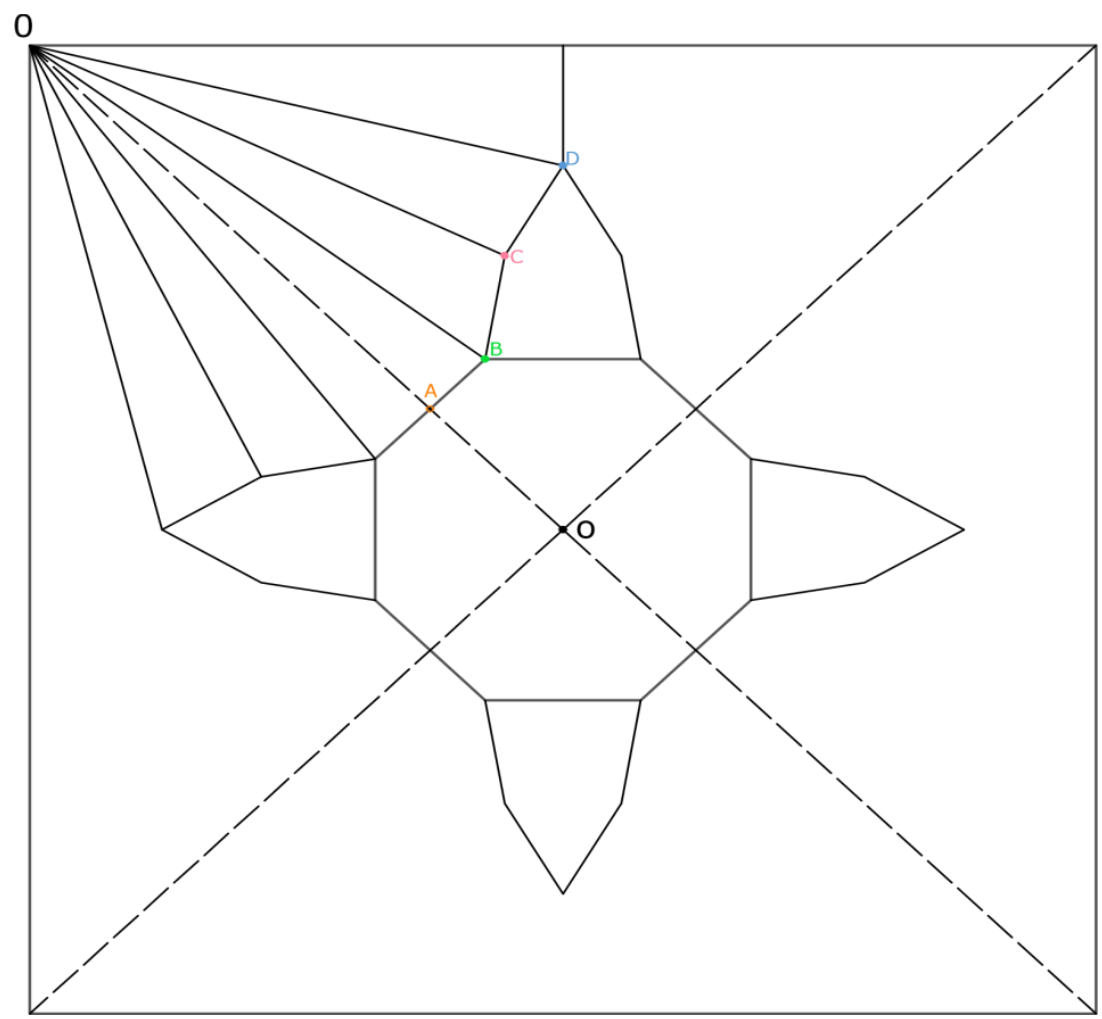

Şekil 12:Divriği Şifahanesi altı kenarlı tonozunun plan tasarımı (Sevda Atak ve Laura Barrale).

$\mathrm{Bu}$ yüksekliğin elde edilebilmesi için, kemerin üzengi hattından (“0”) diyagonallerin kesiştiği nokta ("O") arasındaki uzaklık, yatay eksende tespit edilen ve buradan dikeyde belirlenen aynı uzaklığa ("0-O”) karşılık gelen O' noktası elde edilir. Böylelikle belirlenen O' noktası bütün kenarların yüksekliğidir.

$\mathrm{Bu}$ tüm kenarlar için kabul edilen yükseklikten sonra, her bir kenarın (A, B, C, D) eğimini belirlemek için işlem tekrar eder. Yani "O" noktası ile "A" noktası arasındaki mesafe ölçülüp, yatay düzlemde belirlenir. Böylelikle buradan, bütün kenarlar için kabul edilen yüksekliğe kadar olan dikey iz düşümü çizilerek A' noktası elde edilir. Ya da aynı işlem, "0" noktasını merkez alan bir çemberin, eğimi belirlenmek istenen kenara teğet geçtikten sonra, yatay düzlemde oluşturduğu noktadan, O' noktasına çizilen dikey ile 
de elde edilir. Bundan sonraki süreç tonozun bir çeyreğinin yarısında yer alan bütün kenarlar için (A, B, C, D) aynı şekilde devam eder (Şekil 13).

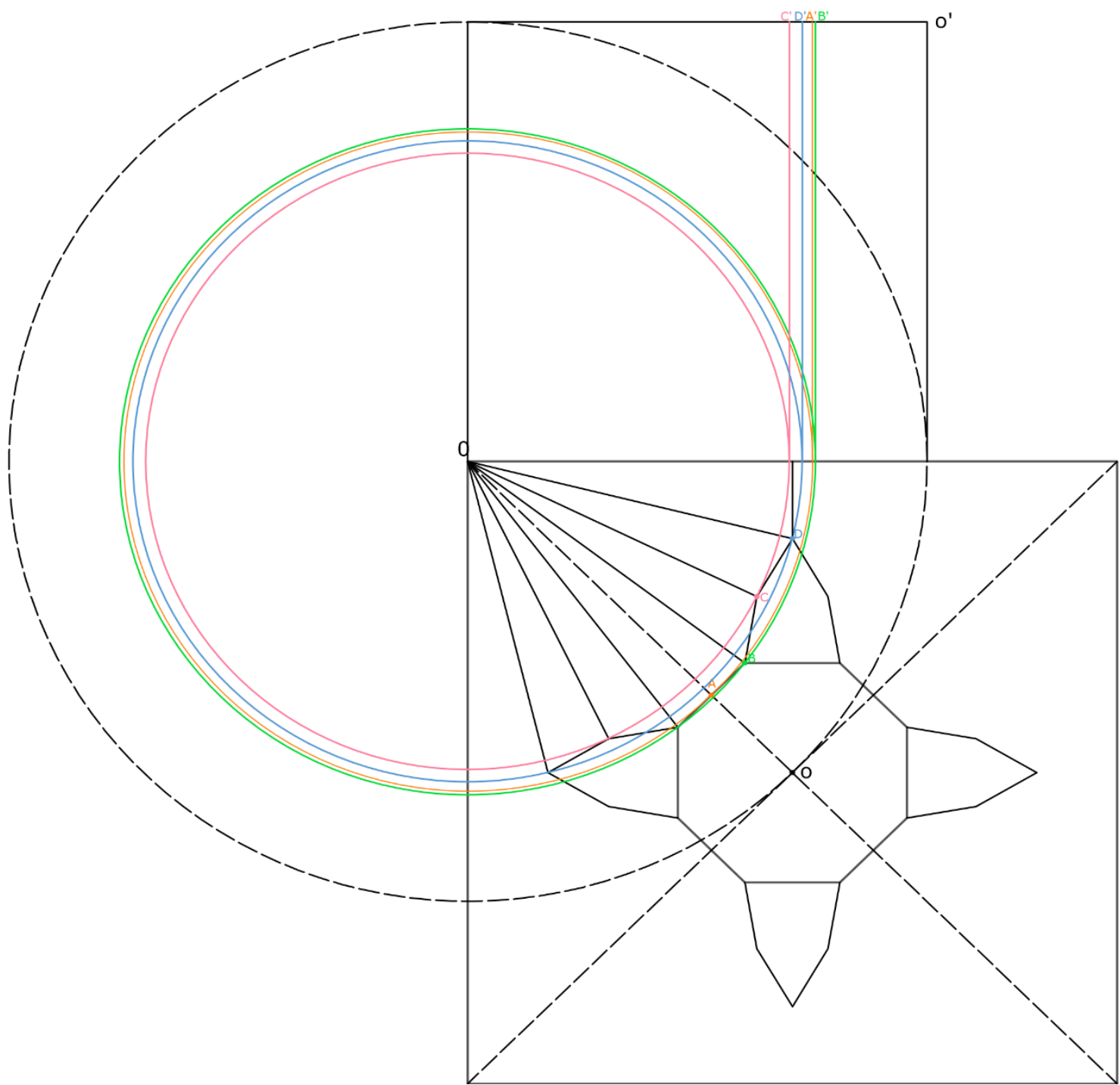

Şekil 13: Divriği Şifahanesi altı kenarlı tonozunun her bir kenarı için uygulanan işlem sıralaması (Sevda Atak ve Laura Barrale).

Daha sonra kenarın çevre yayı, üzengi hattından tepedeki $A^{\prime}$ noktasına bağlanır. Bu işlem; plan üzerinden " 0 " noktasından A' noktasına bir yay çizilerek gerçekleşir. Böylelikle yayın merkezinden başka bir dik yay, yatay düzleme uzatıır. Elde edilen nokta " $\mathrm{C}_{\mathrm{A}}$ " noktasının çemberinin merkezini belirler. Aynı işlem " $\mathrm{B}$ ', $\mathrm{C}$ ' ve $\mathrm{D}$ "' noktaları içinde tekrarlanır (Şekil 14). 


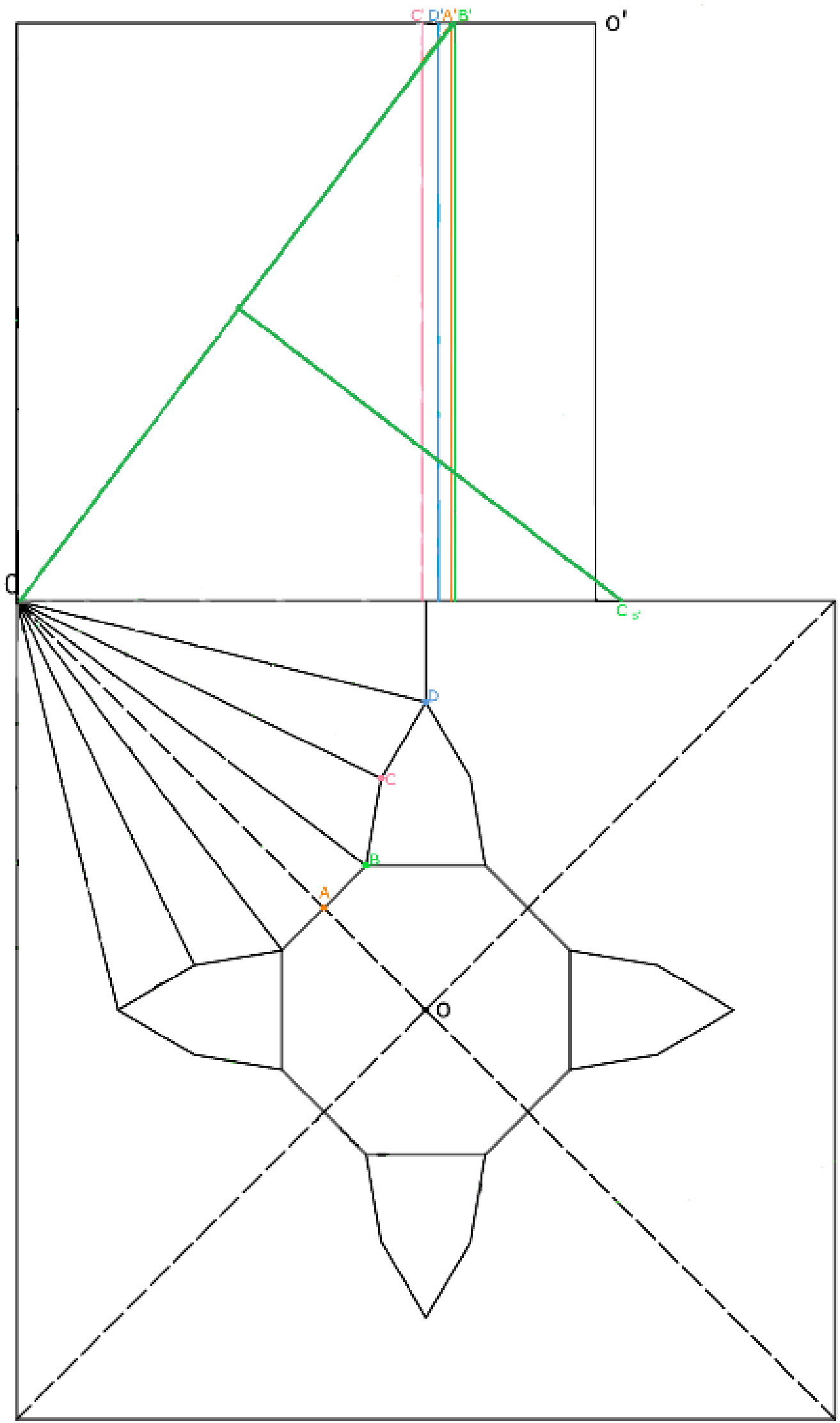

Şekil 14: Divriği Şifahanesi altı kenarlı tonozunun kesit üzerinden B yayının çember merkezinin $\left(\mathrm{C}_{\mathrm{B}^{\prime}}\right)$ bulunması (Sevda Atak ve Laura Barrale). 
Her bir kenar için merkezi farklı olan çemberler çizildikten sonra, yani her kenar için " $\mathrm{C}_{\mathrm{A}^{\prime}}, \mathrm{C}_{\mathrm{B}}, \mathrm{C}_{\mathrm{C}}$ ' ve $\mathrm{C}_{\mathrm{D}}$ ", çember merkezlerinin elde edildiği noktalardan sonra, kenar tonozunun sıralarını belirlemek gerekir. Bu işlem için çemberin merkezinden eşit aralıklarla kemerin içliğine, sıra sayısı kadar (incelenen tonozda sekiz sıradan oluşmaktadır) yaylar çizilir (Şekil 15). Noktaları belirlenen bu sıralara yatayda karşılık gelen dikler eklenir. Aynı işlem dikeyde de gerçekleşir. Bu dikeydekilere teğet olacak şekilde merkezi "0" noktası olan daireler çizilir. Bu dairelerin plan üzerinde oluşturdukları iz düşümleri, daha sonra her bir sıranın kesim yerlerini belirlemeye yardımcı olacaktır. Bütün bu işlemler her bir kenar için tekrarlanır (Şekil 16).

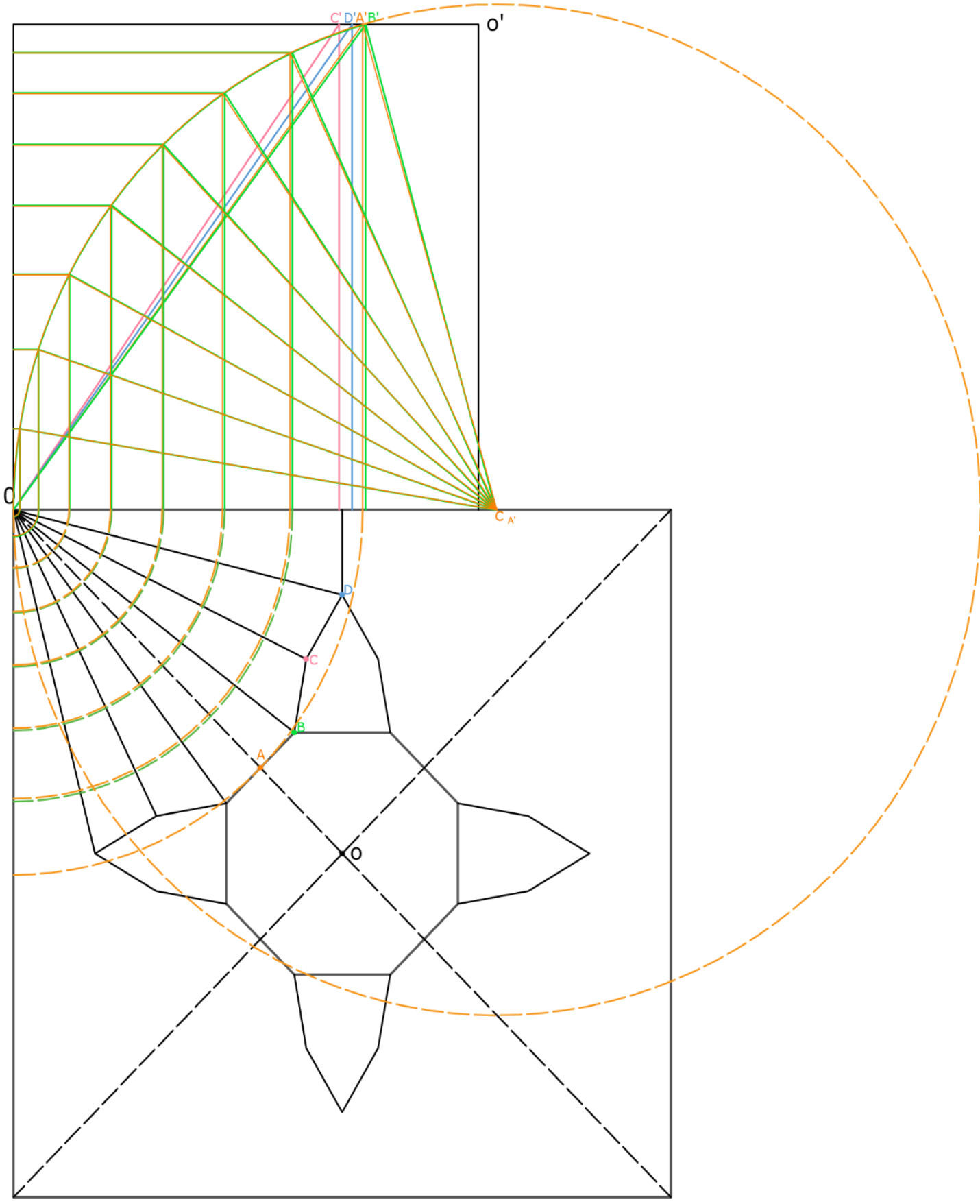

Şekil 15: Divriği Şifahanesi altı kenarlı tonozunun kenar sıralarının belirlenmesine yardımcı olan yayların çizimi (Sevda Atak ve Laura Barrale). 


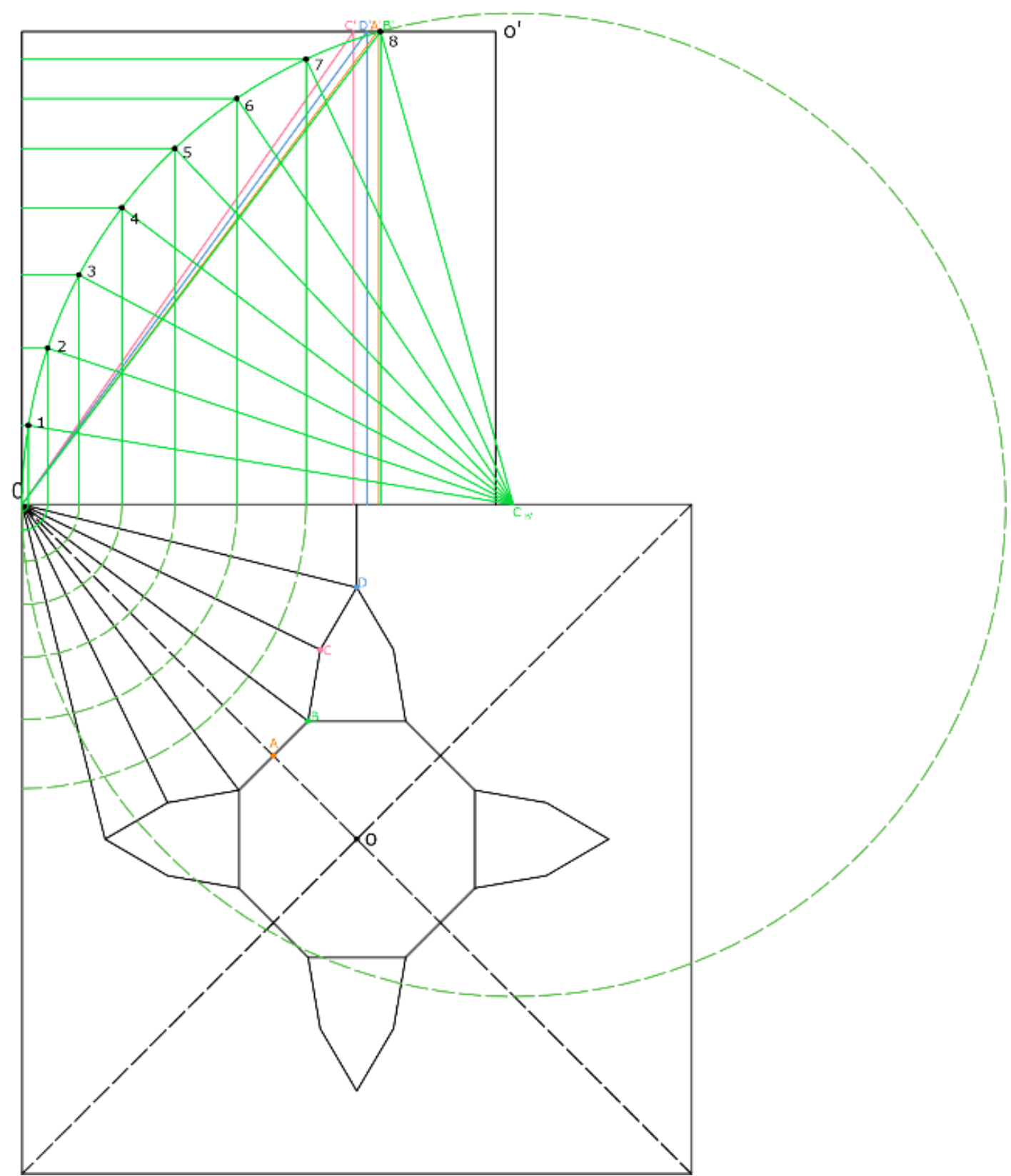

Şekil 16: Divriği Şifahanesi altı kenarlı tonozunun "B" kenarının kesim sırasını belirlenmesinde uygulanan işlem aşaması (Sevda Atak ve Laura Barrale).

Planda, kenarlara ait olan " 0 " merkezli daireler (kesik çizgiler ile gösterilmektedir) ile " 0 " noktasından ve "A, B, C, D" noktalarından geçen kenarlar arasındaki kesişimden elde edilen noktalar birleştirilir (Şekil 17). Kesme taş yataklarının birleştirilebilmesi için doğru sıra " $D, C, B, A$ " şeklindedir. Elde edilen bu geometrik kuruluş, yani "A, B, C, D" kenarlarının kesim yatağını belirleyen bu hat, dikey yarı eksenine doğru çeyreğin diğer yarısına kopyalanır. Böylelikle, tonozun bir tam çeyreği için kesme taş yataklarının sırası elde edilir. Dolayısıyla tonozun her bir çeyreğinin bütün sıralarını da planda belirlemek mümkün olur (Şekil 18). Sonuç olarak tonozun kenarlarını oluşturan kesim yatak sıraları hazır olduğuna göre (Şekil 19), plan üzerinden şablonlar aracılığı ile bu sıralar taşa aktarılarak kesme işlemi gerçekleşir. 


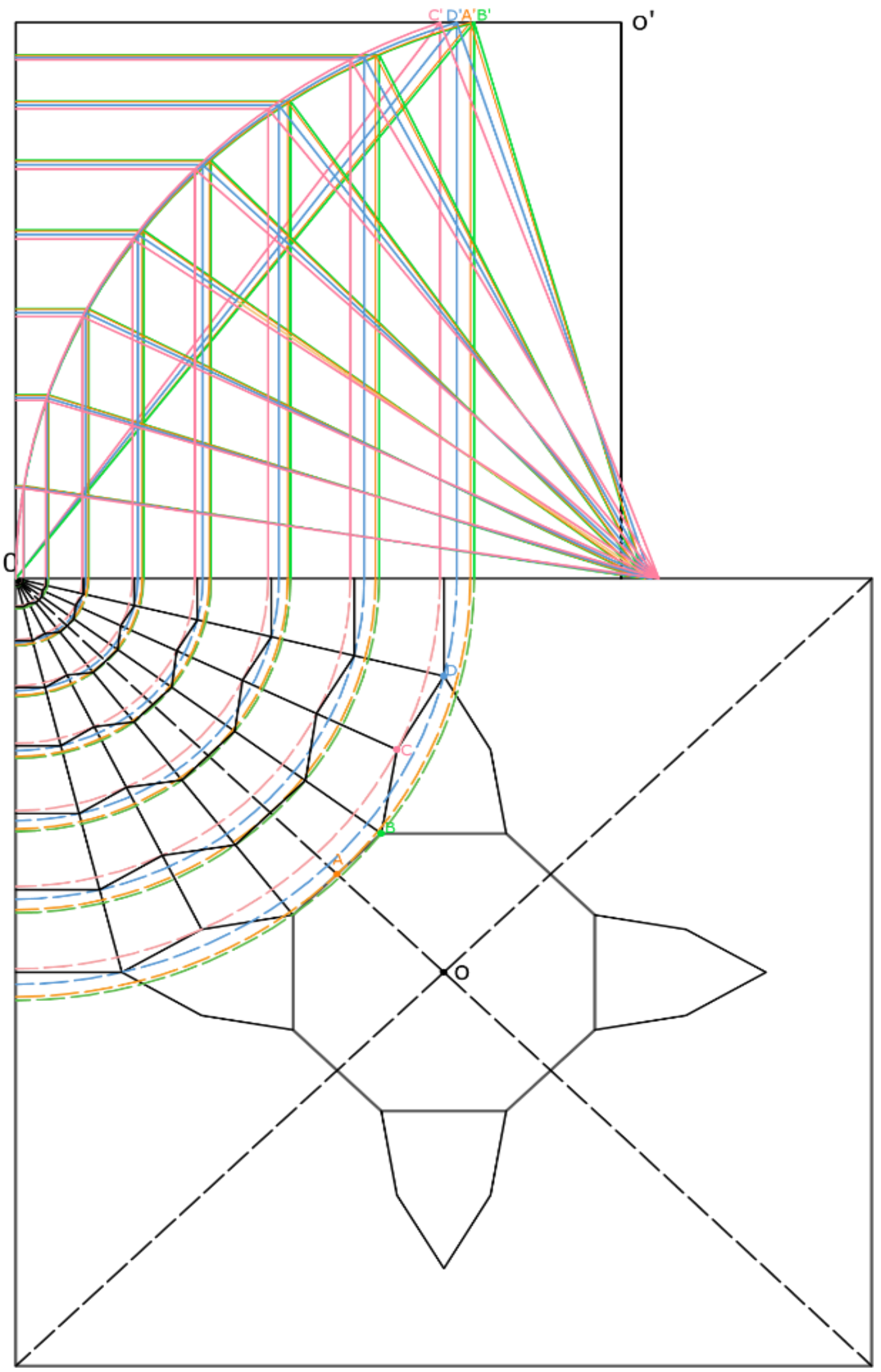

Şekil 17: Divriği Şifahanesi altı kenarlı tonozunun kenar sıralarının belirlenmesi için "0" noktasından ve "A, B, C, D" noktalarından geçen kenarlar arasındaki kesişimden elde edilen noktaların birleşimi (Sevda Atak ve Laura Barrale). 


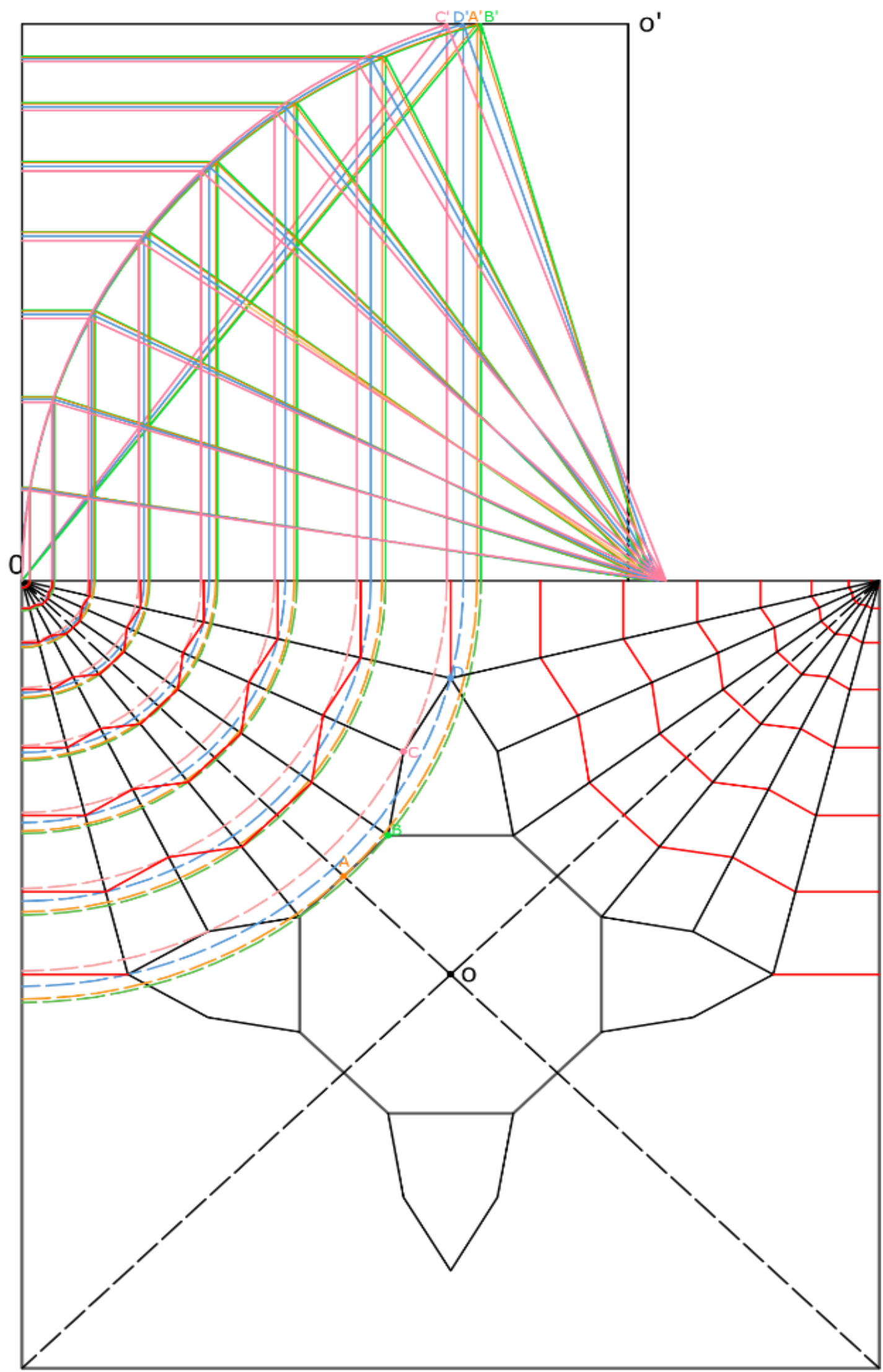

Şekil 18: Divriği Şifahanesi altı kenarlı tonozunun kenar sıralarının belirlenmesi ve diğer çeyreğine kopyalanması (Sevda Atak ve Laura Barrale). 

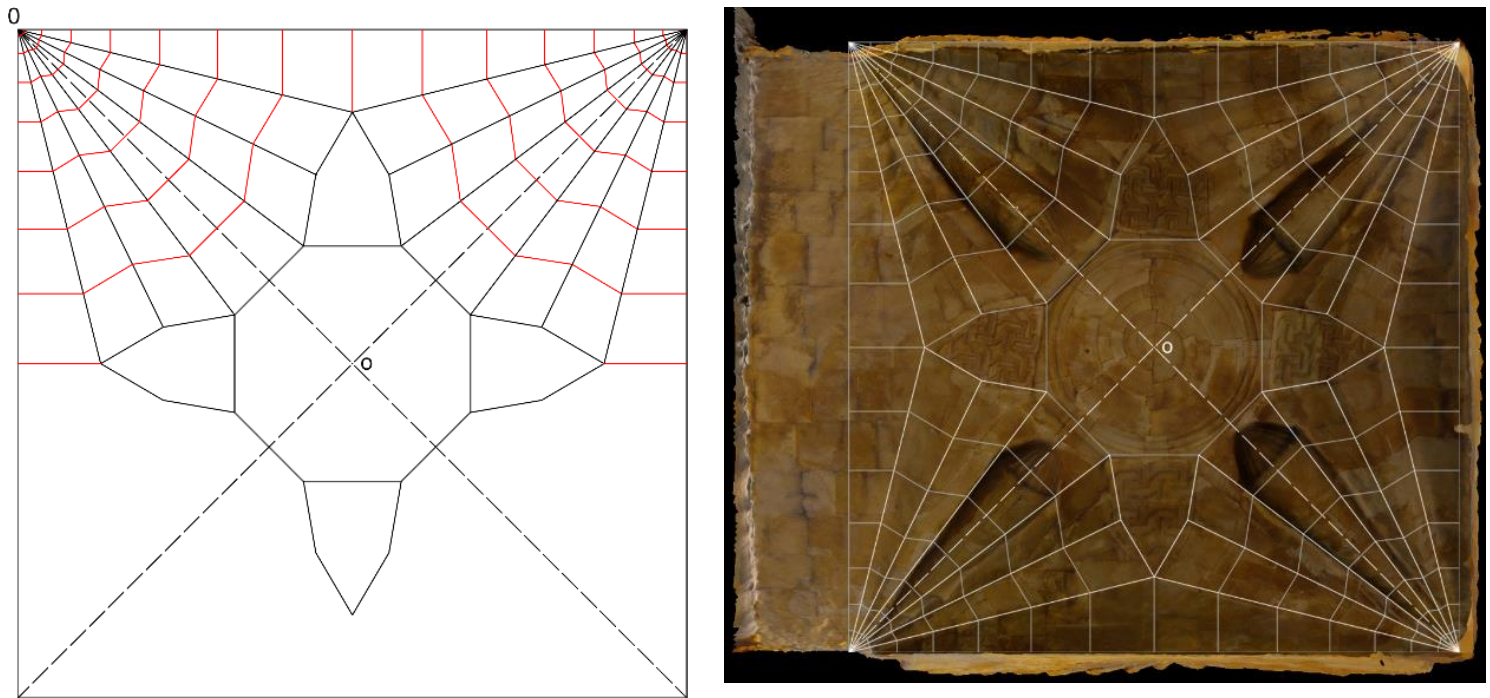

Şekil 19: Divriği Şifahanesi altı kenarlı tonozunun kesme taş yataklarının sırası ve bunların tonoz üzerindeki yeri (Fabrizio Agnello ve Laura Barrale).

\section{Değerlendirme ve Sonuç}

Madrid Taller de Construcción Gótica'da yapılan deney, kesme taşların kesimi ve montajı işlemlerinde bazı hilelere başvurmayı gerektirdi. Sonuç olarak bu hile, prefabrik blokların sekiz yerine dokuz sıraya bölünmesini sağladı. Böylelikle tonozun impostasını oluşturan altı sıradan ilk üçü ve sonraki üç sırayı birbirlerine ekleyerek, hepsini tek bir seferde çalışma fırsatını doğurdu. Bunun üzerine ilk adım, plan üzerinden üçüncü birleşmeye denk gelen sıra, bir kâğıt yardımı ile şablonu çizilerek taş bloğuna aktarııır. Böylelikle taş bloğu üzerinde, kesim hatları çizilmiş olan bu üçüncü sıranın olduğu tepe noktasından, başlangıç noktasına doğru, bütün kenarlar için dikey doğrultuda bir raspa dişli eğe yardımı ile oyularak kesme işlemi gerçekleşir. Daha sonra kenarların sahip olduğu gerçek eğriyi verebilmek için kesme taş üzerinde İspanyolca'da "baibel" ${ }^{15}$ olarak tanımlanan bir aletten yardım alınır. Bu aletin sahip olduğu form, kemerin iç yüzeyindeki eğriye karşılık gelen bölümle aynı eğri doğrultusundadır (Şekil 20). Öyleyse eğriyi elde edebilmek için, bir ahşap ya da bir karton yardımı ile plan üzerinden kemerin sahip olduğu eğimin şablonu çıkarılır. İncelenen durumda, tonozun kemer eğrisinin üzerine yerleştirilen basit bir karton ile şablonu çıkarılarak kemer eğrisinin sahip olduğu form kolaylıkla elde edilir. Elde edilen eğri, dikey olarak oyulan kesme taşlar üzerine yerleştirilerek ve bu eğri doğrultusunda yine bir raspa dişli eğeden yardım alarak yontma işlemi gerçekleşir. Böylelikle tonozun kenarları için gerçek eğim elde edilir (Şekil 21).

\footnotetext{
${ }^{15}$ Baibel, Fransızca biveau 'dan türetilmiş olan, İspanyolca bir terimdir. İtalyanca'da hiçbir karşılığı bulunmamaktadır (Palacios Gonzalo, 2015, s. 32). Bundan dolayı bu araştırmada İspanyolca'daki haliyle kullanılması uygun görülmüştür.
} 


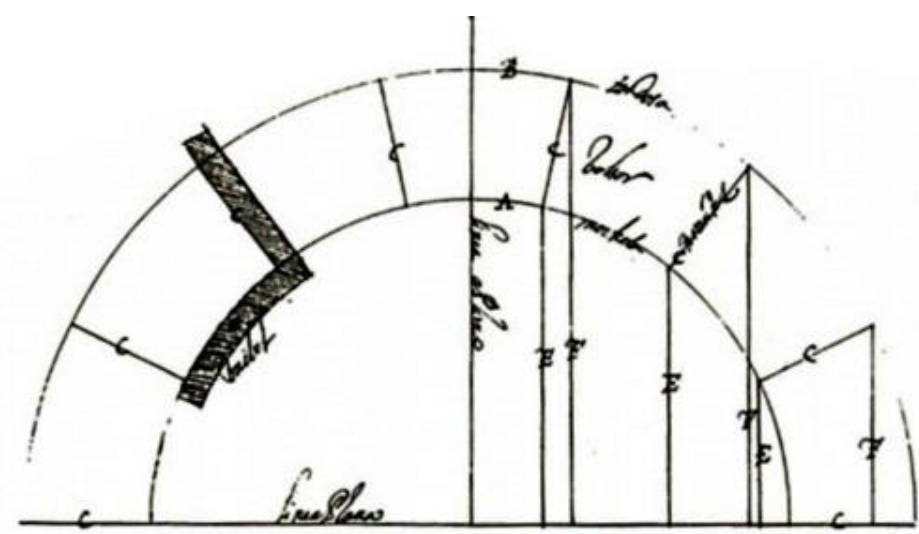

Şekil 20: Baibel (De Vandelvira, 1591, s. 4)
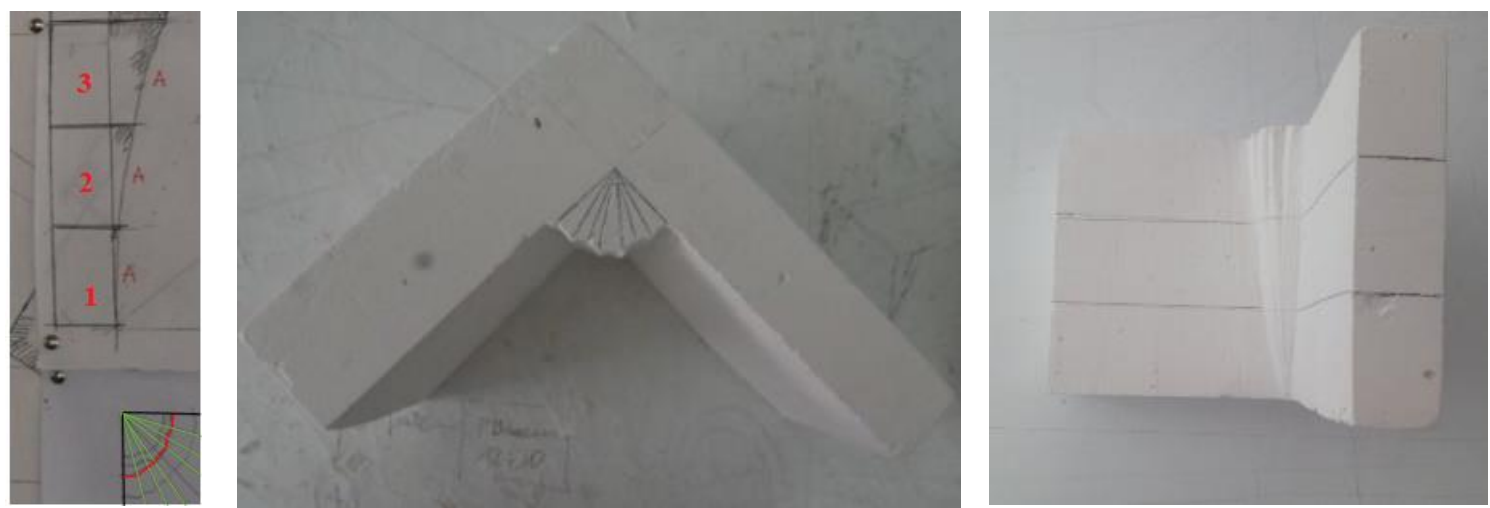

Şekil 21: Divriği Şifahanesi altı kenarlı tonozunun ilk üç parçadan oluşan sıralarının atölyedeki işlem kolaylığı için tek bir blokta gerçekleşen kesim işlemi ve montajı (Sevda Atak, 2017).

Sonraki üç sıra için, yine, plan üzerinden bir kâğıt yardımı ile şablonu çizilerek taş bloğunun üst yüzeyine aktarılır. Ancak burada, bir önceki gibi kesim işlemi sıfır noktasından değil, doğal olarak taşın alt yüzeyine aktarılacak olan ilk üç sıranın yüksekliğinden başlar. Yani taş bloğunun üst yüzeyine altıncı sıranın planı çizilirken, alt yüzeyine üçüncü sıranın şablonu çizilir. Böylelikle kesim işlemi aşağıdan yukarıya doğru bir öncekinin aksine üçüncü sıranın bitiş noktasına doğru gerçekleşir. Bundan sonraki kesim süreci ise öncekinin tekrarı şeklindedir (Şekil 22). Böylelikle ilk eğimli montaj yatağına karşılık gelen yüksekliğe ulaşılarak, tonozun impostasını oluşturan bu üçlü sıradan meydana gelen iki parça birleştirilir (Şekil 23).
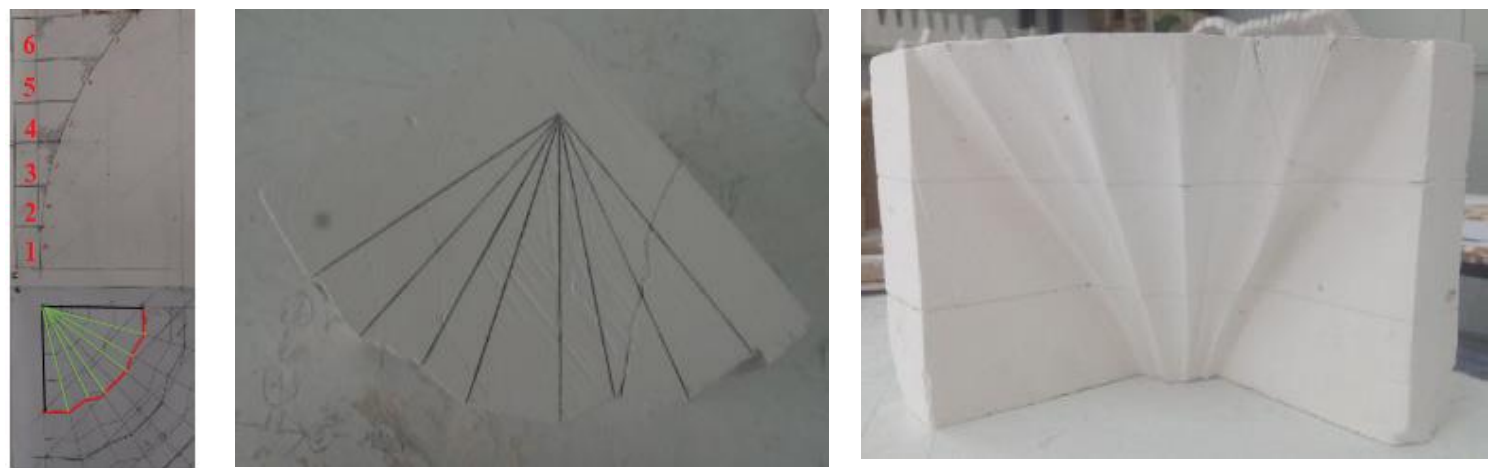

Şekil 22: Divriği Şifahanesi altı kenarlı tonozunun ikinci üç parçadan oluşan sıralarının atölyedeki işlem kolaylığı için tek bir blokta gerçekleşen kesim işlemi (Sevda Atak, 2017). 

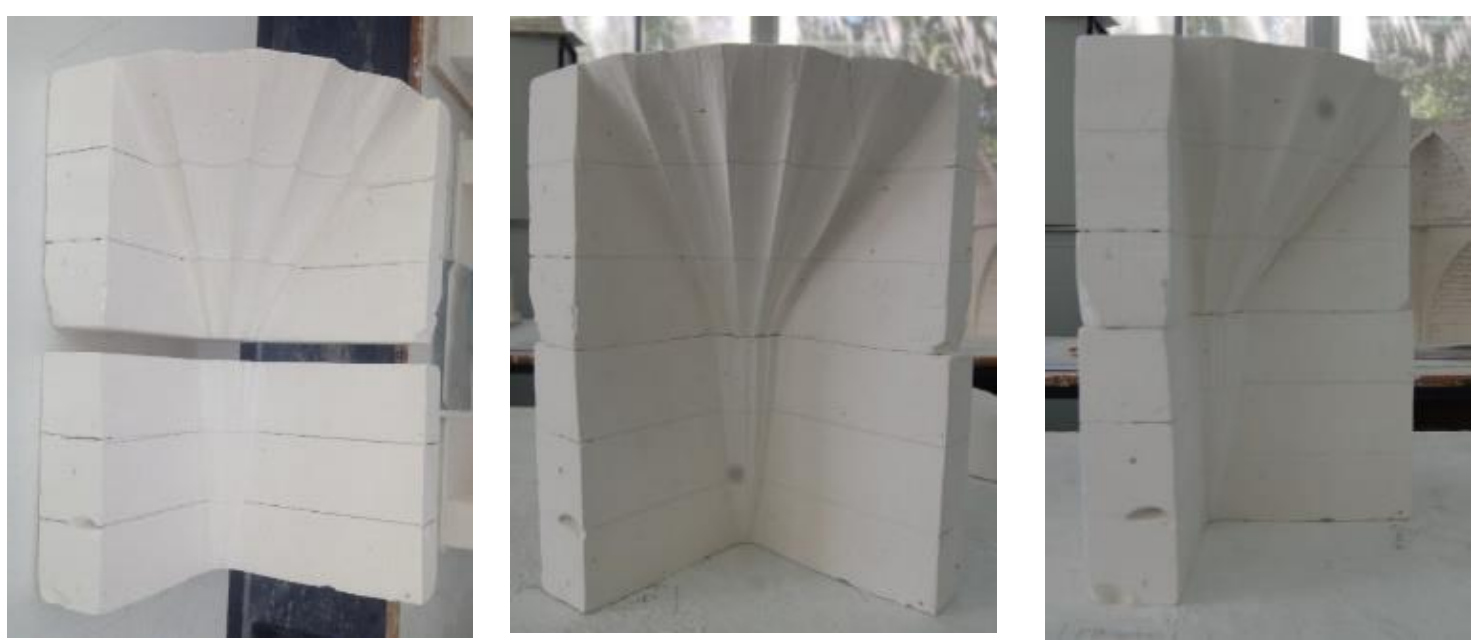

Şekil 23: Divriği Şifahanesi altı kenarlı tonozunun iki parçadan oluşan bütün yatay yataklı olarak kesilen ilk altı sırasının (impostasının) montajı (Sevda Atak, 2017).

Yatay olmayan diğer sıralar için ise işlem tek tek yapılır. Şekil 15'in plan kesitinde daha iyi görüldüğü üzere, merkeze yakın olan son üç sıra diğerlerine nazaran daha incedir. Bu durumda yatay kesme işlemi gerçekleşirse çok keskin açılara sahip olan bu sıralar kısa zaman içerisinde tonozun yıkılmasına neden olabilir. Bu yüzden varsayılan hipotez üzerinden ve atölye çalışmasını daha kolay hale getirmek için dokuz sıraya bölünen tonoz hatlarının son üç sırasının eğimli olarak kesilmesi uygun görülmüştür. Çünkü Divriği Şifahanesi ana eyvan altı kenarlı tonozu için XIII. yüzyılda uygulanan bu geometrik sistem, büyük olasılıkla benzer bir çözümü doğurmuş olmalıdır. Aksi halde, bu daha dar açılı merkeze yakın kenar hatlarının kesim işlemi için eğimli bir kesim yerine, impostayı oluşturan yatay sıralarda olduğu gibi bir kesim işlemi gerçekleştirilip inşa ediyor olsaydı, olağanüstü bir geometriye sahip olmakla beraber, kendi döneminde altı kenarlı olarak tek olmayı başaran bu tonozun, günümüze kadar gelmesi mümkün olmayabilirdi. Sonuç olarak tonozun merkezine yakın olan bu sıralar için kesim işlemi, eğimli olarak yapılır. Bu işlem için planın kesiti üzerinden, kesilmek istenen kenar sırası öncelikle planda belirlenir (Şekil 24). Elde edilmek istenen sıra, yine bir şablon yardımı ile hatları çizilerek taş bloğuna aktarılır. Burada tonozun impostasını oluşturan yatay yatakların aksine, şekil verilecek olan kesme taşın hatları, taş bloğunun sadece üst ve alt yüzeylerine aktarılmakla kalmaz, aynı zamanda profilinde de, elde edilmek istenen sırasının kesme taşı, tonozun kesitinde görüldüğü gibi bu kesilecek olan taş bloğunun profilininde yer almalıdır (Şekil 25). 


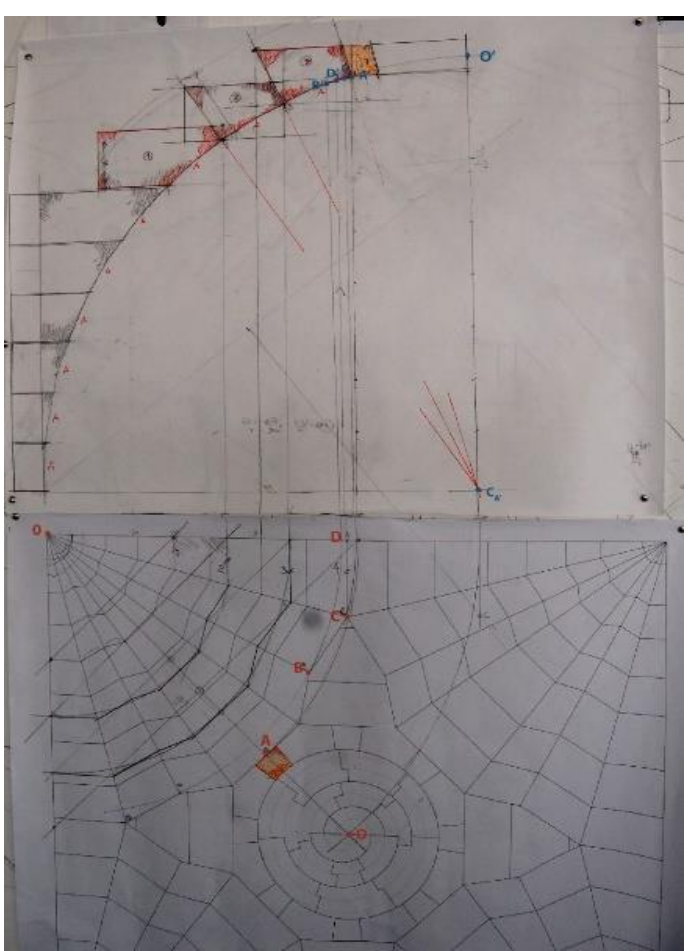

Şekil 24: Divriği Şifahanesi altı kenarlı tonozu için plan üzerinde işaretlenen " 3 " numaralı kesme taşın şablonu (Sevda Atak, 2017).

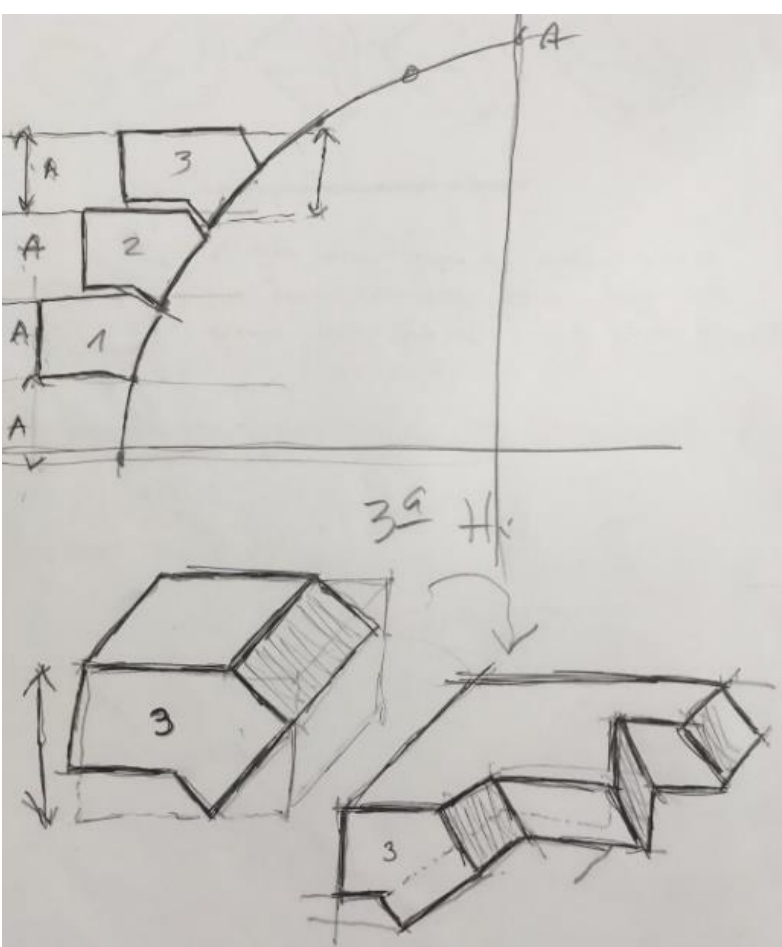

Şekil 25: Divriği Şifahanesi altı kenarlı tonozunun merkezine en yakın ve "3" numaralı olarak adlandırılan kesme taşı için işlem aşama eskizi (Sevda Atak, 2017).

Bundan sonraki süreç bu eğimli kesilecek olan her sıra için tek tek plan üzerinden, taş bloğuna aktarılarak ve işaretlenen yerlerden kesilerek işlem devam eder (Şekil 26-2728).
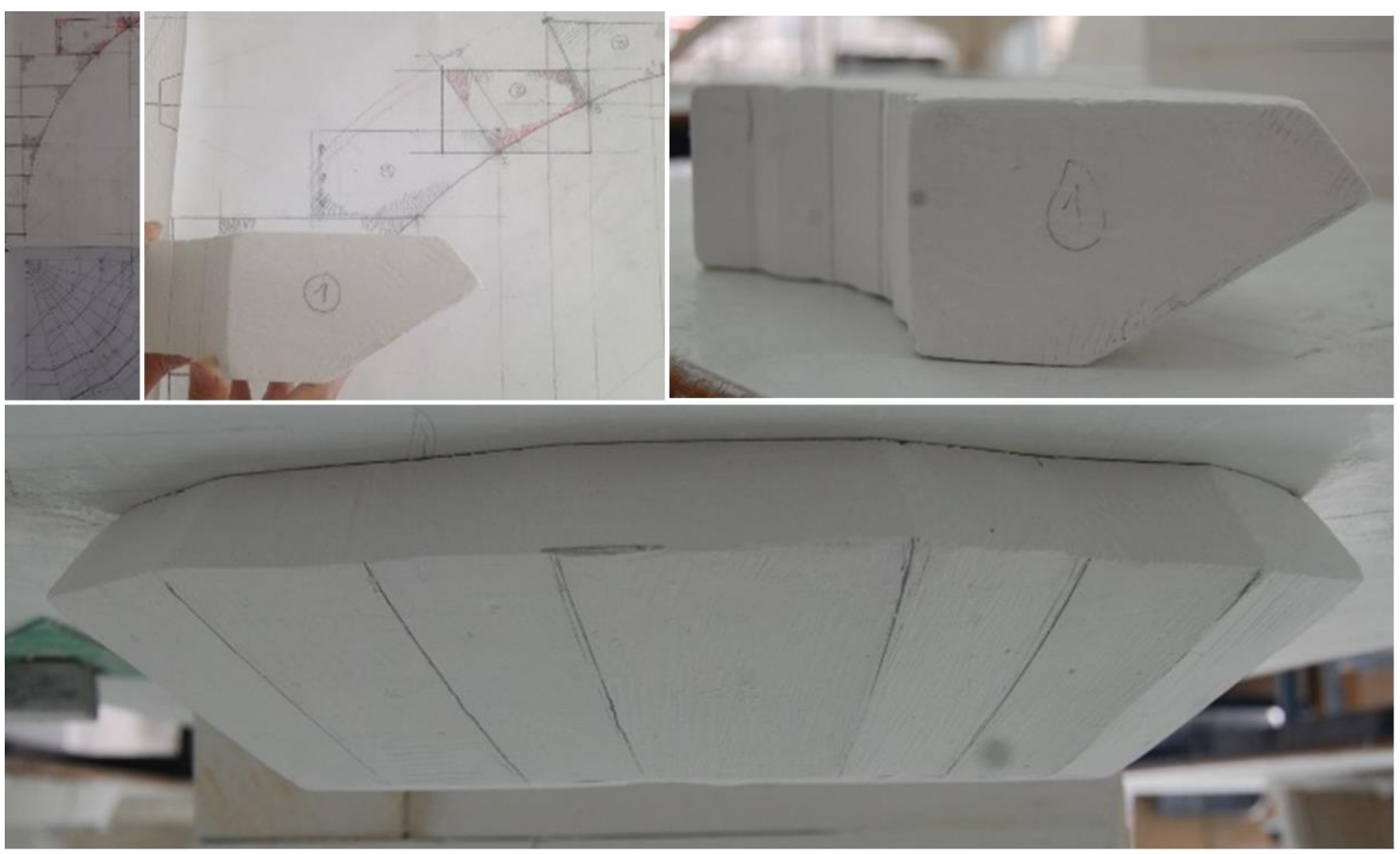

Şekil 26: Divriği Şifahanesi altı kenarlı tonozunun impostasından sonraki ilk eğimli sıranın geometrik yapısı ve kesimi (Sevda Atak, 2017). 


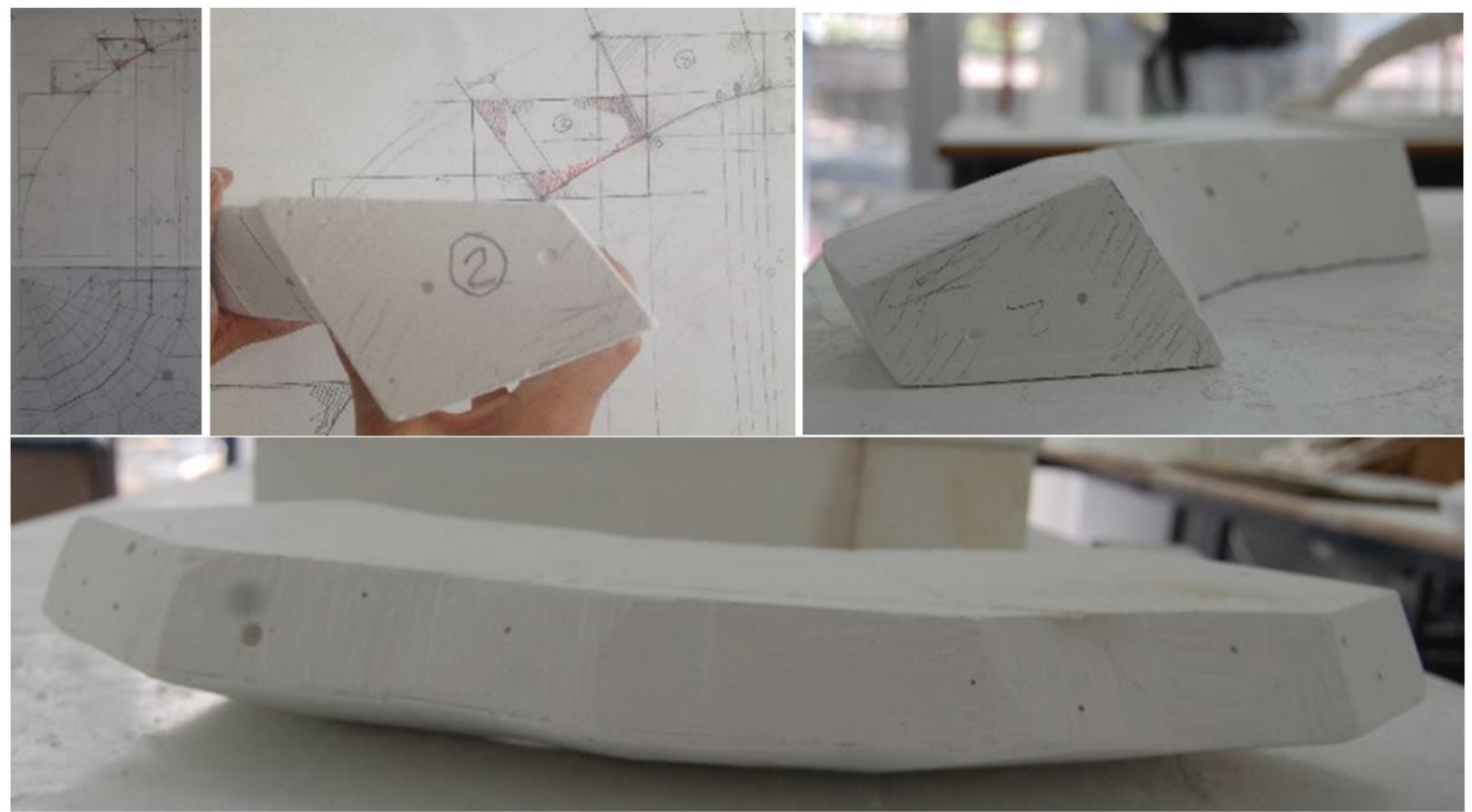

Şekil 27:Divriği Şifahanesi altı kenarlı tonozunun ikinci eğimli sıranın geometrik yapısı ve kesimi (Sevda Atak, 2017).

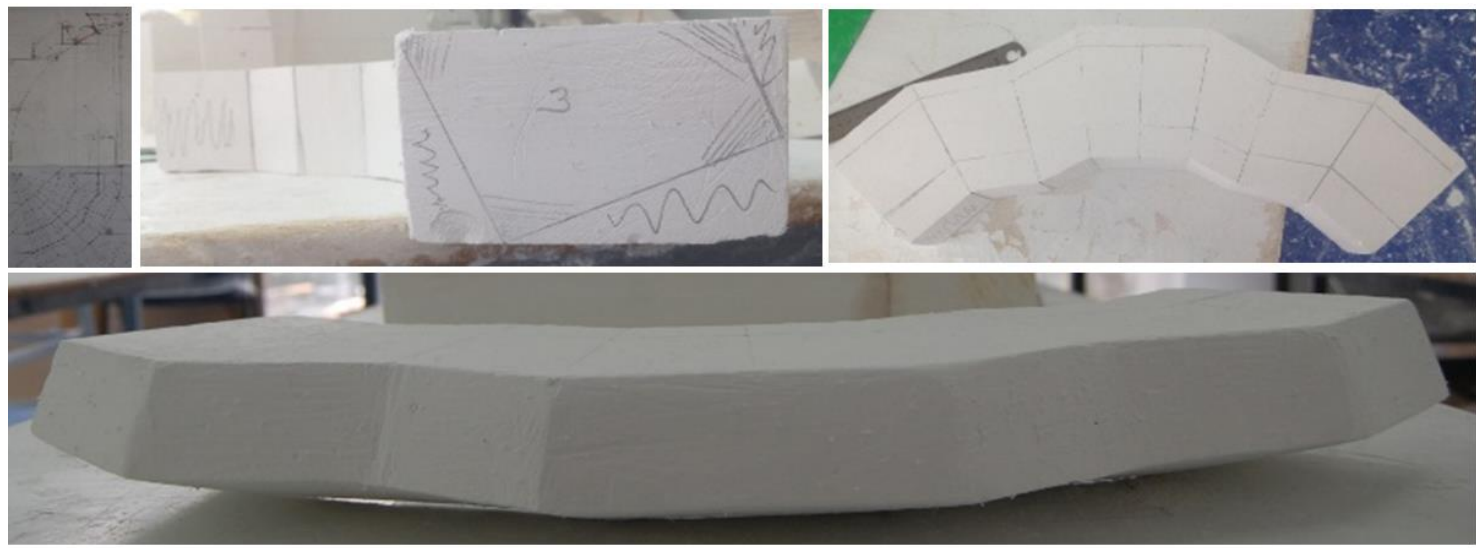

Şekil 28: Divriği Şifahanesi altı kenarlı tonozunun merkezinin hemen bitişiğinde olan üçüncü eğimli kesme taşının geometrik yapısı ve kesimi (Sevda Atak, 2017).

Tonozun yatay sıralarına nazaran eğimli olan son üç sıranın kesimi şantiye için daha zor ve pahalı olan bir işlemdir. Çünkü bu şekilde ilerleyen kesim, impostanın yer aldığı yatay sıralardan oluşan kesime nazaran daha çok taş israfına neden olmakla beraber, kesme taş şablonlarının seri şekilde üretilmesinde de zorluklar doğurur. Dahası, daha detaylı ve daha derin bir sterotomiya bilgisi gerektirmektedir. Bu yüzden tonozun başlangıç noktasından itibaren oluşan yatay hatlar ile (impostayı oluşturan kısım) sonrasındaki eğimli sıralar arasındaki fark, malzeme, zaman ve işçi tasarrufu gibi etkenlerin yanı sıra daha düşük maliyeti de beraberinde getirmektedir. Hiç kuşkusuz bu durum, Orta Çağ Anadolusu'nda, bir şantiye için göz ardı edilemeyecek kadar önemli olmalıdır.

Son olarak, gerçekleşen hipotez üzerinden, tonozun kenar sıralarını oluşturan bütün kesme taşlar elde edilerek (Şekil 29) impostayı oluşturan yatay sıralar ile eğilimli sıraları oluşturan parçalar birleştirilir (Şekil 30-31-32). 

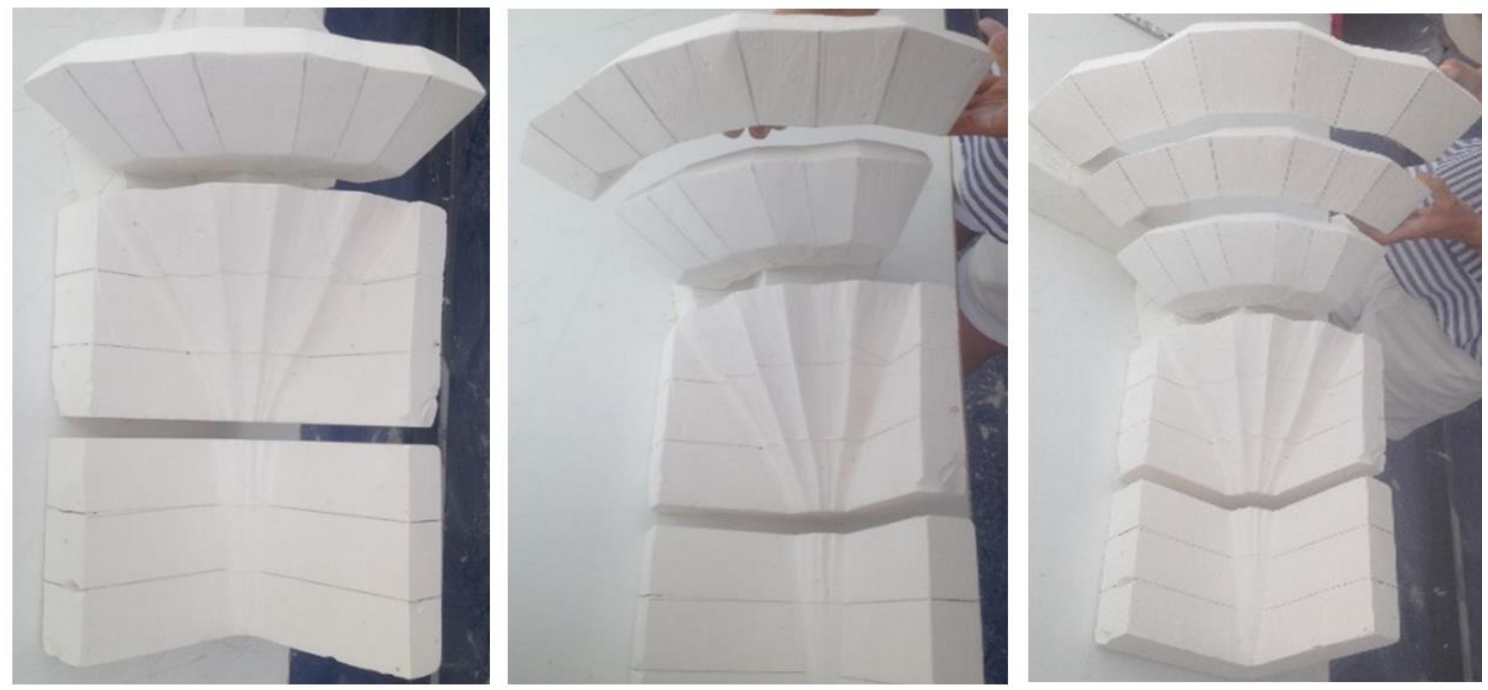

Şekil 29: Divriği Şifahanesi altı kenarlı tonozunun impostası ile eğimli sıralarından oluşan kesme taşlarının montaj aşaması (Sevda Atak, 2017).
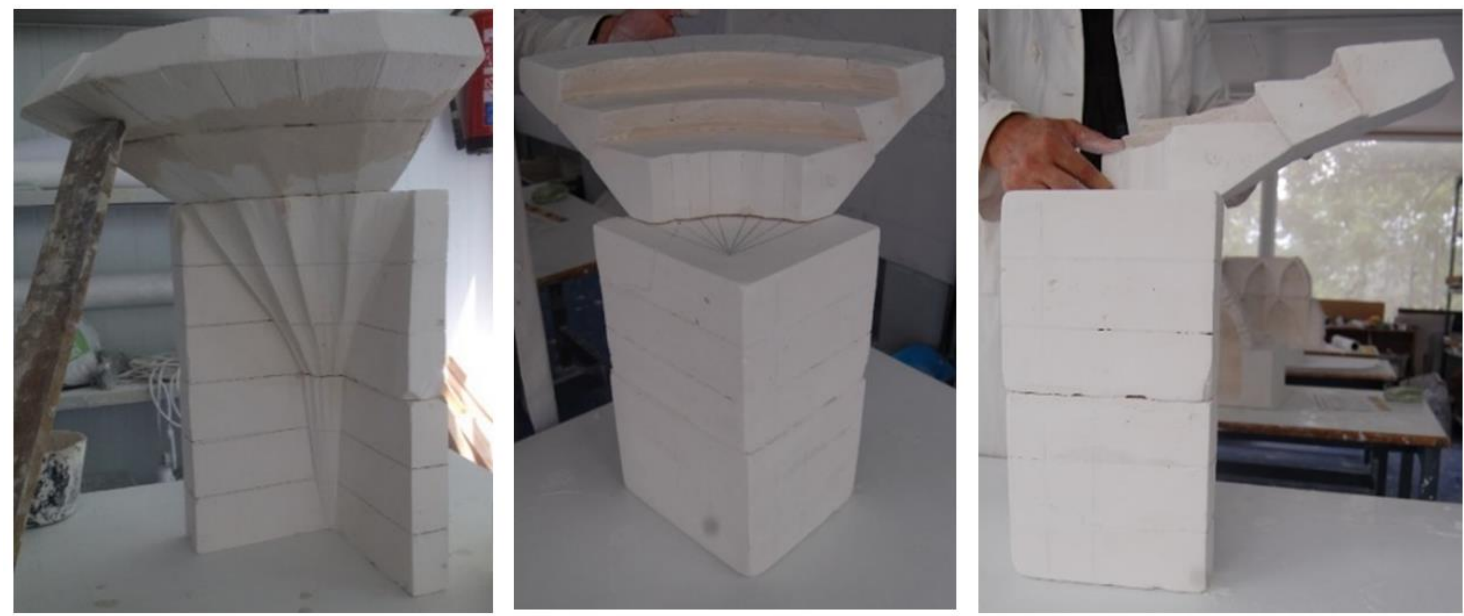

Şekil 30: Divriği Şifahanesi altı kenarlı tonozunun kenar hatlarının montajı (Sevda Atak, 2017). 


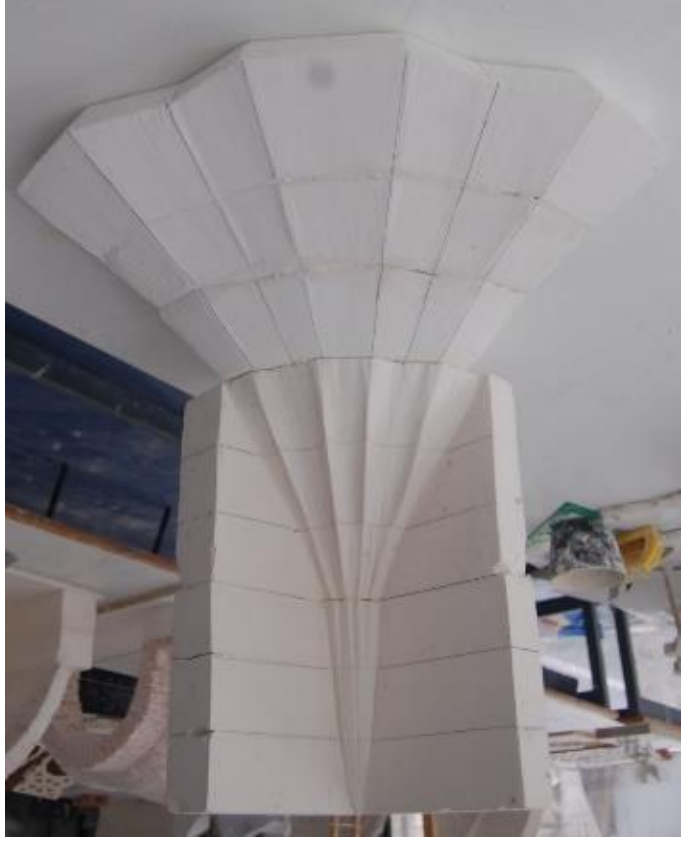

Şekil 31: Divriği Şifahanesi altı kenarlı tonozunun Madrid atölyesinde elde edilen küçük modeli (Sevda Atak, 2017).

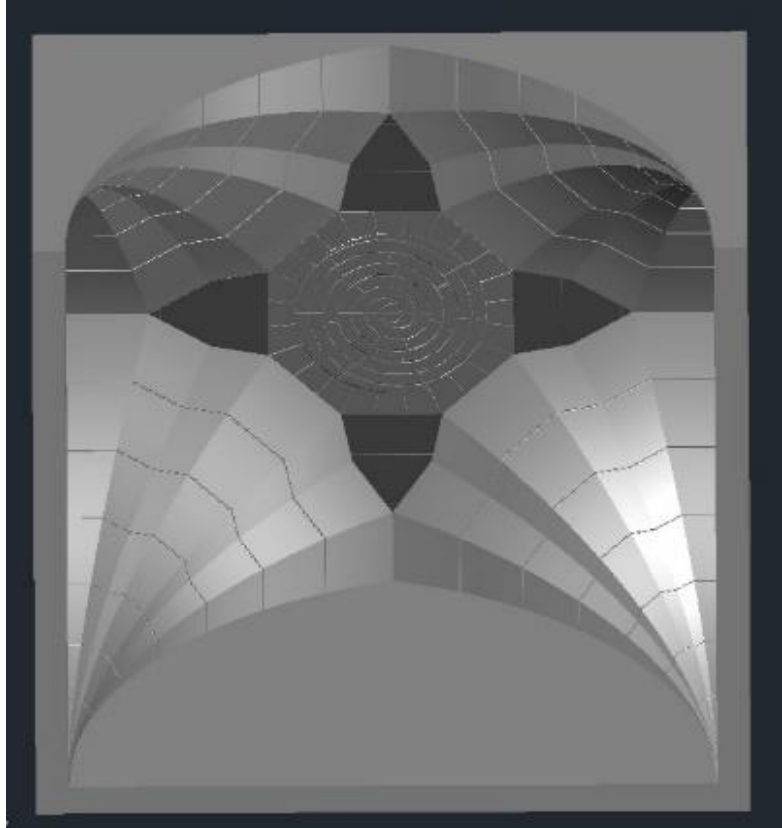

Şekil 32: Divriği Şifahanesi ana eyvan altı kenarlı tonozunun perspektif görünüşü (Diego Martinez Moreno, 2017).

Madrid Taller de Construcción Gótica'da gerçekleştirilen yeniden yapılandırma deneyimi sırasında geliştirilen bu hipotezin doğru olması durumunda, Divriği Ulu Cami ve Şifahanesi'nin bütün kenar tonozları için, bu deneyim potansiyel olarak uygulanabilir. Tonozun inşasında gerçekleşen yatay yöndeki kesme taş sıralarının yerine getirildiğini varsayarak, impostanın çok yüksek olarak inşa edildiği söylenebilir. Bir tekniğin özenle hazırlanması doğal olarak belli avantajların yürütülmesinde fayda sağlamıştır. Bu fayda, kesme taşların standardizasyonu açısından, kalıpları hazırlayıcı yatkınlık ve bununla beraber geometrik taslakları kolaylaştırmasının, Anadolu bölgesinin birçok tonozlu yapısını, Selçuklu döneminden itibaren karakterize eden kenar tonozların ${ }^{16}$ çoğalmasının bir kaynağı olabilir. Bu durum, aynı zamanda kenar tonozların inşasında, Selçuklu ustalarının çalışma yöntemini de göstermektedir. Belkide bu yapı sistemi ile kenar tonozların tekniğinde kullanılan farklılıklara, kendi becerilerini göstererek meydan okuyan yapı ustalarını bu durum cesaretlendirmiş ve aşama aşama kenar tonozların inşasındaki geometrik karmaşıklık derecesini artırmış olabilir.

\footnotetext{
${ }^{16}$ Anadolu'da XIII. yüzyıldan XV. yüzyıla taşın inşaatı ve kesimi: Divriği Ulu Cami ve Şifahanesi (Orjinal dili İtalyanca olan: Costruzione e Taglio della Pietra in Anatolia dal XIII al XV secolo: La Moschea e l'Ospedale di Divriği) adlı doktora tezinde, Selçuklu Anadolusu'ndan başlayıp Akdeniz kıyıları boyunca, Avrupa'ya doğru, Suriye ve Mısır'dan geçerek kenar tonozların stereotomiyaları üzerine bir güzergah hazırlanmaya çalışılmıștır. Tabii ki bu, bir zincirin bağlantılarını bir araya getirmek amacıyla, temalar hakkındaki kısmi bilgilerle koşullandırılmış bir yoldur. Bu yol, Orta Doğu'daki Orta Çağ stereotomiya deneyimlerini ile 15. ve 16. yüzyıllar arasındaki, Avrupa'nın Valensiya Krallığı, Kuzey Almanya ve Güney İtalya gibi bazı yerlerinde ansızın gün ışığına çıkan kenar tonozları arasında bir bağlantı kurulmaya çalışılmışıır. Bunun sonucunda, araştırmanın Anadolu sınırlarını içeren kısmı göstermektedir ki, Anadolu'da Selçuklular ile beraber mimari yapıların üst örtüsü için deneyimlenmeye başlayan kenar tonozların sayısı küçümsenmeyecek kadar çoktur. Özellikle vurgulamak gerekir ki, Divriği Ulu Cami ve Şifahanesi'nde yer alan kenar tonozlar, Anadolu'da mevcut olan diğer kenar tonozlardan daha erken tarihlidir. Bununla beraber, kendisi ile aynı yüzyıla eşlik eden mimari yapıların üst örtülerinde görülen kenar tonozlara öncülük ettiği de ileri sürülebilir (Atak, 2019; s. 177-207)
} 


\section{KAYNAKLAR}

Atak, Sevda, Costruzione e Taglio della Pietra in Anatolia dal XIII al XV secolo: La Moschea e l'Ospedale di Divriği, 2019.

Atak, Sevda, "Divriği Şifahanesi Ana Eyvan Spiral Merkezli Düz Tonozunun İnşası ve Geometrik Analizi", Uluslararası Hakemli Tasarım ve Mimarlık Dergisi, (19), 2020, s. 69-96.

De Vandelvira, Alonso, Libro de Trazas de Corte de Piedras, El yazması, (bir kopyası Madrid, Mimarlık Fakültesi Kütüphanesi'nde), 1585.

Divriği Ulu Cami ve Darüşşifası, editörler: Y. Önge, S. Bayram, I. Ateş, Ankara 1978.

Kuban, Doğan, Gates of Paradise the Sculpture of Hürremşah at Divriği Ulucami and Şifahane, İstanbul 2010.

Kuban, Doğan, "The Mosque and Hospital at Divriği and the Origin of Anatolian-Turkish Architecture", Anatolica: Annuaire International Pour Les Civilisations De L'asie Anterieure, 2, 1968, s. 122-129.

Kuban, Doğan, Divriği Mucizesi Selçuklular Çağında İslam Bezeme Sanatı Üzerine Bir Deneme, İstanbul 1999.

Kutluay, Sevgi, Divriği Ulu Cami ve Darüşşifası'nın Taş Süsleme Programı, Yüksek Lisans Tezi, vol. I, Hacettepe Üniversitesi Sosyal Bilimler Enstitüsü, Ankara 1988.

Navarro Fajardo, Juan Carlos,Bóvedas de la Arquitectura Gótica Valenciana, Valensiya 2006.

Nobile, Marco Rosario, Architettura e Costruzione in Italia Meridionale (XVI-XVII sec.), Palermo 2016.

Palacios Gonzalo, Josè Carlos, Trazas y Cortes de Canterìa En el Renacimiento Español. Madrid 2003.

Palacios Gonzalo, Josè Carlos, Taller de Construcción Gótica. Workshop on Building Gothic Methods, Madrid 2015,

Pancaroğlu, Oya, "The Mosque-Hospital Complex in Divriği: A History of Relations and Transitions", Anadolu ve Çevresinde Orta Çağ, 3, Ankara 2009, s. 169-232.

Pancaroğlu, Oya, "The House of Mengüjek in Divriği: COnstructions of Dynastic Identity in the Late Twelfth Century", The Seljuks of Anatolia: Court and Society in the Medieval Middle East, editörler: A.C.S Peacock, S.N Yıldız, New York 2012, s. 25-67.

Peker, Ali Uzay, "Imprisoned Pearls: The Long-Forgetten Symbolism of the Great Mosque and Dar al-Shıfa at Divriği",Archaelogy, Anthropology and Heritage in the Balkans and Anatolia, vol. 3, editör: D. Shankland, Istanbul 2013, s. 315-345.

Pérez de los Ríos, Zaragozá Catalán, "Bóvedas de Crucería con Enjarjes de Nervios Convergentes que Emergen del Muro en el Area Valenciana", XIV-XV, Actas del Octavo Congreso Nacional de Historia de la Construcción (Madrid, 9-12 Ekim 2013), 2 
voll., editörler: S. Huerta ve F. López Ulloa, Madrid, Instituto Juan de Herrera-Escuela Técnica Superior de Arquitectura de Madrid, 2013, s.833-842.

Rabasa Diaz, Enrique, "Soluciones Innecesariamente Complicadas en la Estereotomía Clásica”, El Arte de la Piedra. Teoría y Práctica de la Cantería, Cuadernos de Investigación, 1, 2009, s. 50-69.

Rabasa Diaz, Enrique, Forma y Construcción en Piedra: de la Cantería Medieval a la Estereotomía del Siglo XIX, Madrid 2000.

Sakaoğlu, Necdet, Dünya Kültür Mirası Divriği Külliyesi, Hayat Ağacı, Sivas Şehir Kültürü Dergisi, Özel sayı (19), 2012, s. 12-18.

Trevisan, Camillo, Per la Storia della Stereotomia Geometrie, Metodi e Costruzioni, Roma, 2011.

Tükel Yavuz, Ayşıl, "The Geometric Patterns of Anatolian Seljuk Decorated Vaults", Fifth International Congress of Turkish Art, editör: G. Feher, Budapest 1978, s. 863880.

Tükel Yavuz, Ayşıl, Anadolu Selçuklu Mimarisinde Tonoz ve Kemer, Ankara 1983.

Tükel Yavuz, Ayşı, "The Characteristics of Star Vaults in Seljuk Anatolia", Structural Repair and Maitenance of Historic Buildings, vol. 4, 1993, s. 165-192.

Tükel Yavuz, Ayşı, "Yıldız ve Yıldızlı Haç Tonozlar", Sanat Tarihinde İkonolojik Araştırmalar, Ankara 1993, s. 543-578.

Tükel Yavuz, Ayşıl, "Açıklık ve Mekân Örtüleri Terminolojisi", Sanat Tarihinde Terminoloji Sorunları Semineri I, Ankara 2001, s 179, 153-185.

Zaragozà Catalàn, Arturo, Arquitectura Gòtica Valenciana, Siglos XIII-XV, Valensiya 2000.

Zaragozà Catalàn, Arturo,"Cuando la Arista Gobierna el Aparejo: Bòvedas Aristasdas", Arquitectura en Costrucciòn en Europa en Epoca Medieval y Moderna, Valensiya 2010, s. $177-209$. 